\title{
Understanding the Most Important Facilitators and Barriers for Online Education during COVID-19 through Online Photovoice Methodology
}

\author{
İbrahim Doyumğaç ${ }^{1}$, Ahmet Tanhan² \& Mustafa Said Kiymaz ${ }^{3}$ \\ 1 Turkish Education, Adiyaman University, Adiyaman, Turkey, ORCID ID: 0000-0002-8234-7555. E-mail: \\ ibrahim63doyum@gmail.com \\ ${ }^{2}$ Economic and Social Research Center - ESAM (Ankara, Turkey), The University of North Carolina at Greensboro \\ (North Carolina, USA); Adiyaman University, Adiyaman, Turkey. E-mail: tanhanahmet3@gmail.com ORCID iD: \\ https://orcid.org/0000-0002-4972-8591 \\ 3 Turkish Education, Adiyaman University, Adiyaman, Turkey, ORCID ID: 0000-0003-3821-5499. E-mail: \\ mkiymaz@adiyaman.edu.tr
}

Correspondence: İbrahim Doyumğaç, Turkish Education, Adiyaman University, Adiyaman, Turkey. E-mail: ibrahim63doyum@gmail.com or idoyumgac@adiyaman.edu.tr

Received: September 14, 2020

Accepted: October 23, 2020

Online Published: October 26, 2020

doi:10.5430/ijhe.v10n1p166

URL: https://doi.org/10.5430/ijhe.v10n1p166

\begin{abstract}
There are three main research goals in this study including (a) understanding the most important facilitators (support, strength) and complicators (barrier, concern, issues, problems) for online or distance education during COVID-19 from the unique perspective of college students, academicians, and teachers through Online Photovoice (OPV); (b) advocating with the volunteer participants and partners as allies to share the results with the key people and institutions through online avenues to enhance facilitators and address complicators; and finally, (c) investigating participants' attribution of facilitators and complicators based on Ecological Systems Theory (EST) levels. The researchers utilized the adapted Turkish version of OPV to collect and used Online Interpretative Phenomenological Analysis (OIPA) to analyze the data. Community-Based Participatory Research (CBPR) grounded in EST constructed the theoretical framework for the research. In total, 115 participants completed and consented for the study. Sixteen main facilitator-related themes emerged, and the five most expressed were having technology $(n=31$, $35 \%)$, internet $(n=28,32 \%)$, communication $(n=18,20 \%)$, emotions $(n=17,19 \%)$, and economic resources $(n=$ 16, \%18). Thirteen main complicators-related themes emerged, and the five most reported barriers were lacks of technological resources $(n=41,47 \%)$, internet $(n=40,46 \%)$, appropriate learning environments, learning opportunities $(n=32,36 \%)$ appropriate resources for online or distance education $(n=18,20 \%)$, and interaction $(n=$ 14, 16\%). Participants attributed the facilitator and complicators to EST levels respectively as follows: individual/intrapsychic factors $(84 \% ; 69 \%)$, microsystem $(45 \% ; 59 \%)$, exosystem $(36 \% ; 43 \%)$, and macrosystem (34\%; 44\%). The researchers provided practical recommendations. The researchers obtained an institutional review board approval for this study.
\end{abstract}

Keywords: online and distance education, COVID-19, online photovoice (OPV), community-based participatory action research, ecological systems theory, coronavirus

\section{Introduction}

Covid-19 pandemic, often referred to as the Coronavirus Disease, is also known as the Novel Coronavirus 2019 (World Health Organization [WHO], 2020). WHO reported COVID-19 as a dangerous and threatening disease on January 30, 2020. On March 1, 2020, it was declared as a pandemic (Cucinotta \& Vanelli, 2020). The COVID-19 pandemic that affects the global health started in China in November 2019 (Liu et al., 2020; Tanhan et al., 2020). The virus spread globally in a short period of time (Huang et al., 2020) and led to very serious and unexpected biological, psychological, social, spiritual and economic problems (Tanhan, 2020). During the COVID-19 outbreak, people experienced several behavioral problems (Cortese et al., 2020), including boredom, depression, anxiety, fear (Arslan et al., 2020b; Çıtak \& Pekdemir, 2020), burnout, uncertainty, conflicts, aimlessness, being caught up with negative news, and some other psychopathological issues (Tanhan, 2020). They experienced unpleasant feelings, thoughts, and physical emotions (Tanhan et al., 2020) and these cases may lead to severe problems such as suicide 
(Mamun \& Griffiths, 2020). During the challenging pandemic, the lack of professional knowledge, fake news that circulate on the internet, and the psychological consequences of these perceptions led to further problems for the individuals (Tanhan et al., 2020).

The COVID-19 has led to serious problems for many individuals (Arslan, 2020; Tanhan et al., 2020) and seriously affected college students (Akyol et al., 2020; Çetin \& Anuk, 2020; Gençalp, 2020; Gumusgul \& Aydoğan, 2020; Kürtüncü \& Kurt, 2020; Sarıtaş \& Barutçu, 2020; Tanhan, 2020). According to the researchers from different countries including Turkey (Tanhan et al., 2020), China (Cao et al., 2020) and the USA (Rose, 2020), it was reported that college students experienced various problems during the COVID-19 pandemic (Viner et al., 2020).

In studies conducted well before the COVID-19 pandemic in Turkey, it was reported that college students experienced several problems (Uğur et al., 2020), and it could be suggested these problems were due to contextual issues including biopsychosocial spiritual and economic factors. It could be suggested that college students experienced problems in in various countries before the COVID-19 pandemic (Becker et al., 2015; Tanhan, 2019; Tanhan \& Francisco, 2019). To address the problems experienced by the students both in Turkey and the world and to comprehend their quality of life during the COVID-19 pandemic, some researchers strongly recommended to employ Online Photovoice (OPV) methodology (Arslan et al., 2020b; Uğur et al., 2020; Tanhan et al., 2020). This is important because Coronavirus has affected students, instructors, and educational organizations around the globe (Mailizar et al., 2020; Toquero, 2020). All these led a fast and unexpected transition to distance and virtual learning and various obstacles and challenges (Crawford et al., 2020; Kaur, 2020). Educational institutions are also centers to socialize and meet some basic social human needs (McCarthy, 2020; Tanhan, 2020; Tanhan et al., 2020). The researchers stressed how lack of healthy social interactions may lead to some serios biological, psychological, social, spiritual and economic issues from a micro level to macro level. Researchers also highlighted individuals and especially communities with disprivileges and called for key people and institutions to act accordingly (Emir Öksüz, 2020; Tanhan, 2020; Tanhan \& Strack, 2020).

\section{Online-Distance Education}

The education conducted with digital tools is referred to using several terms, including distance, online, open, flexible, blended, and mixed education to name a few. Furthermore, different names are used for online education such as all internet-based online courses and organized courses and programs (Sayk1l, 2018; Tanhan, 2020). Online education is the most extensively used term to describe all information and communication technologies-based learning approaches, although "e-learning," "distance learning," "distance education" and "online learning" have also been used (Lee, 2010: 278). Distance education is a form of education that enables the physically-distant learner(s) and the facilitator(s) of the learning activity around planned and structured learning experiences via various two or multi-way mediated media channels (Sayk1l1, 2018). In this way distance education allows interactions between/among learners, facilitators, as well as between learners and educational resources without requiring being online at the same time.

The review of the above-mentioned definition revealed that concepts such as e-learning, distance learning etc. that were used for online education were also used for distance education. In online education, courses are mostly instructed online and require an internet connection during instruction. Distance education, on the other hand, includes online education, and the courses are instructed online or offline where video and audio are uploaded on a system to conduct the educational process. Since distance education includes online education, distance education and online education terms are used interchangeably in the present study. In fact, the term online education was mostly preferred in the study. Therefore, in the presents study online education is used to indicate all forms of education except for face-to-face education.

According to Lee (2010), online education is the educational approach facilitated by social learning and information technologies that allow communication between instructors and students via ordinary interaction. Most online instructors/academicians have little experience in many subjects, similar to the students. The most prominent among these is e-learning. E-learning is a common term that covers digital learning technologies and used to describe this process (Nichols, 2008). In addition to online education and e-learning, the concept of distance education has also been widely used. Distance education is the foundation of online learning.

Based on the above-mentioned definitions and discussions, various concepts have been used to describe non-face to face and distant education, and generally it was called e-learning, online education, and distance education. According to Allen and Seaman (2008), several universities and other educational institutions provide online education to expand their student base. According to Lee (2010), the popularity of online education has affected several novel approaches and the popularity of online education would increase in the future. 
Especially to prevent the interruption of education during the COVID-19 pandemic, most of primary and secondary educational institutions around the world provided online courses (e.g., distance education, video education, open education; Tanhan, 2020). During the COVID-19 pandemic, education in primary and secondary schools and colleges was mostly conducted online. The effectiveness of distance education is still unclear. The pandemic forced universities to switch their programs to one of online delivery overnight. This led administrators to adopt to this unexpected change as soon as possible (Liguori \& Winkler, 2020).

COVID-19 did not only affected college students but also primary, middle and high school students, parents, teachers, academics, and especially people with special needs in different ways. Due to the transition to distance education, teachers and academicians could not determine the method they need to adopt, and limited one-on-one interaction with the students complicated education during pandemic (Tanhan, 2020). This process has been more difficult for people with socioeconomic disprivileges (Tanhan, 2020; Tanhan et al., 2020) because some researchers found that even during normal times people with disprivileges are not served well (Emir Öksüz \& Brubaker, 2020; Tanhan \& Francisco, 2019). On the one hand, online education (distance education, open education) is convenient for the students and academics (Allen et al., 2002; Tanhan, 2020), while leading to certain difficulties and disadvantages at the same time (Tanhan, 2020). Furthermore, certain studies indicated that online education (distance education) could be as efficient/effective as face-to-face education (Lack, 2013; Wu, 2015). However, Liu et al. (2020) reported that the internet-enabled and tangible user interface allows the students to perceive online education positively. In contrast, online education could lead instructors and students to resort to unethical plagiarism (Ubell, 2017). Lucky et al. (2019) discussed that the rate of students who resort to academic fraud in online education (distance education) was 12 times higher than the rate in face-to-face education. Furthermore, according to certain studies, there was no significant difference between learning outcomes in online and face-to-face education (Allen \& Seaman, 2010; Allen et al., 2002; Biner et al., 1995; Brown \& Liedholm, 2002). Allen et al. (2002) reported that distance education had advantages due to virtual reality and imaging capabilities. Certain online education factors such as quality, flexibility, sensitivity, communication and technical support services positively affect student views on online education (Helgesen \& Nesset, 2007; McGorry, 2003; Rovai, 2003). Paechter and Maier (2010), in a study that compared online learning and face-to-face learning, reported that student perceptions about online learning were positive. Thus, enforcement of high integrity standards should be taken seriously in online education (Singh \& Hurley 2017), as it has long been a challenge in face-to-face classrooms, as evidenced by decade-long studies (Diekhoff et al. 1996; Haines et al., 1986; Stiles et al., 2018; Vandehey et al., 2007). Tanhan (2020) also found online education to be one of the most important facilitators for some students while it was the most important barrier for some others during the Covid-19 process. The researchers, therefore suggested that education institutions that switched to online or distance education without preparations during the COVID-19 pandemic, should pay attention to the above-mentioned factors and provide flexibility for the students and instructors, recognize their sensitivity, and provide technical support to conduct more efficient online or distance (open) education services. Especially during the COVID-19 pandemic, there is a greater need for online (distance) education. This leads to the question of the sufficiency and readiness of the online (distance) education infrastructure of the nations and colleges. The online or distance education services and facilities available in nations or universities vary. "This would create issues regarding the quality of online courses between the online education providers and service providing countries" (Lee, 2010: 277).

The review of the studies on online learning (e-learning) and education demonstrated that the studies were conducted on topics such as the quality of education in online learning, the quality of online learning compared to face-to-face education, the online education infrastructure of an institution or organization, and the perceptions and views of instructors and students about online education (Alexander \& Golja, 2007; Bliuc et al., 2007; Coates et al., 2005; Lester \& King, 2009; Lee \& Lee, 2008; Lee et al., 2009; Levy, 2007). The findings reported by these studies demonstrated that the advantages and disadvantages of online education were not addressed, although the positive and negative aspects of online (distance) education were partially discussed and online education was investigated with already known methods. It could be argued that online education was not analyzed with the novel Online Photovoice (OPV) methodology developed by Tanhan and Strack (2020). Thus, it is the purpose of this paper to understand the facilitating (positive) and challenging (barriers, issues) aspects of online education during the pandemic based on the views of instructors and students using the photovoice technique developed by Tanhan and Strack (2020). The aim of the present study was to determine the facilitating and complicating factors associated with online education based on the views of instructors and students at colleges that switched to online education during the COVID-19 pandemic, with the novel OPV methodology. 


\section{Theoretical Framework: The Employment of Online Photovoice with Community-Based Participatory Research Based on Ecological Systems Theory in COVID-19}

The theoretical study framework included Ecological Systems Theory (EST), Online Photovoice (OPV), and Community-Based Participatory Research (CBPR), and active social advocacy. Based on this theoretical framework, the Online Interpretive Phenomenological Analysis (OIPA) approach was employed in data analysis. Active advocacy was another very important concept that complemented all the above-mentioned approaches and made the study data even more meaningful, and especially constituted the infrastructure of OPV, CBPR and the study.

\section{Ecological systems theory (EST)}

Bronfenbrenner (1977) developed EST to provide a comprehensive developmental framework about multiple factors that provide layers of influence on individuals throughout their lives. The first of the five main systems defined by Bronfenbrenner (1979) that interacts to create and influence the dynamic daily contexts for the individual is the microsystem (close settings such as home, school, etc.), the second is the mesosystem (the system that includes the relationships between the microsystem and the exosystem), the third is the exosystem (the system that includes indirect factors such as media, neighbors, social services, local governments and institutions), and the fourth is the macrosystem (the system that includes culture, government, economy and social attributes) (Bronfenbrenner \& Evans, 2000). Different scholars from different disciplines have benefited from EST and suggested to employ its perspective to research and education while paying attention to contexts of people which they live within (Arslan et al, 2020a; Kiymaz \& Doyumğaç, 2020; Tanhan, 2019; Tanhan, 2020).

\section{Community-Based participatory research (CBPR)}

Community-Based Participatory Research (CBPR) is a key component of psychological and public health intervention strategies conducted with the cooperation of communities and partners to identify the problems (challenges, issues) or available resources (advantages, facilitators) to improve the quality of life. Although different authors used various terminologies such as partner/stakeholder development (Tanhan \& Francisco, 2019; Tanhan \& Strack, 2020), community-based participatory research (Tanhan et al., 2020), participatory action research (Minkler, 2000) and school-community partnership (Arslan \& Tanhan, 2019; Arslan et al., 2020a), these descriptions indicate the objective of collaborating with the community for the community to solve problems and improve the quality of life. In the present study, the CBPR term was preferred since it is easy to read and to remember. CBPR rejects a top-down approach to understand the issues. CBPR is an alternative research paradigm based on the collaboration between researchers and individuals, groups, communities and institutions to solve social problems and contribute to their well-being (Tanhan \& Strack, 2020). Tanhan and Strack (2020) worked with a community of 118 individuals that included students, academicians, civil servants, workers and their families at a university in the USA using OPV. The authors (Tanhan \& Francisco, 2019; Tanhan \& Strack, 2020) investigated the biopsychosocial, moral and economical attributes that make the lives of these people easier or more difficult within this community. To improve the facilitating factors and to address the difficulties in the most effective way, the authors conducted active social advocacy with the participants and achieved significant results. Active social advocacy is a key concept that is the basis of CBPR and OPV (Tanhan, 2020).

\section{Active social advocacy}

The authors emphasized the significance of collective decision-making, learning and research for the participants to reduce injustice at individual, micro, exo and/or macrosystem levels based on biopsychosocial, spiritual and economic aspects (Goodhart et al., 2006; Tanhan, 2020; Tanhan \& Francisco, 2019). The role of active advocacy, in other words, increasing the available resources and addressing the experienced problems by conveying the findings of the collective work to relevant and authorized individuals, institutions and organizations, was emphasized. Although advocacy was mentioned as active advocacy, social advocacy, active social advocacy or simply advocacy in the literature, these refer to the same concept. The concept entails informing the relevant and authorized individuals, institutions and organizations about the research to tackle the experienced problems and to increase the general well-being. In other words, the research goes beyond the academic level, voluntary participants and stakeholders but actively strive for contextual changes. The authors of the present study employed the concept of active social advocacy, since it has a more positive and inclusive connotation when compared to the other concepts of advocacy that include only the term advocacy or social advocacy (Tanhan, 2020). Active social advocacy means the following: It goes one step further than the advocacy of scientists at the academic level as observed in each scientific research, conference proceeding or article where the findings are stored in shelves, laboratories or clinics. Tanhan (2020) explained a researcher with active social advocacy perspective is proactive and reach out relevant 
individuals, communities, institutions and organizations to plan research with and for them and utilize the results to enhance wellbeing and address issues.

\section{Online photovoice (OPV)}

Tanhan and Strack (2020) developed Online Photovoice (OPV) to develop a more effective and rich research method by reaching diverse participants and to obtain meaningful and powerful results by reducing the time spent by researchers and participants. Thus, the OPV method or technique costs less time, material resources, and contextual factors and is more useful in cases where face-to-face interaction is impossible or very difficult due to a pandemic or endemic, security problems, conflicts or natural disasters. The OPV method developed by Tanhan and Strack (2020) was based on the conventional photovoice method/technique developed by Wang and Burris (1997). In the present study, OPV method or OPV technique were employed interchangeably, since previous studies referred to photovoice as both a method and a technique. In conventional photovoice, the 8-13 participants are grouped and a short face-to-face training is provided by a researcher. Later, the participant takes photographs, writes accompanying stories and meets with the author and other participants and shares the photographs and stories with the whole group. This has some important advantages: groupwork and listening to different stories for several hours each day allows each participant enough time to tell their story, and researchers who specialize in listening to the participants spend time with the participants in empathy (Tanhan, 2020; Tanhan \& Strack, 2020). In addition to these advantages, the conventional photovoice method also has significant limitations: It requires a significant time for both the researcher and the participants, it is not anonymous, it could only be conducted with a small number of participants such as 8 and 13, requires advanced specialization and the researcher to physically be present in the environment, and it generally focuses on the problems (Tanhan, 2020; Tanhan \& Strack, 2020). Furthermore, the researchers highlighted the requirement for the participants to allocate time for each session and fall behind daily work, and the impossibility of photovoice applications during events such as COVID-19, are also important limitations of conventional photovoice. Thus, Tanhan and Strack (2020) developed OPV and Tanhan (2020) adapted it to Turkish so that OPV includes the advantages of the conventional photovoice and removes the limitations. In this way OPV is a much more effective and innovative methodology to be employed in various contexts.

Online photovoice (OPV) has three objectives. The first is to empower the participants by allowing them to express the most important factors that facilitate or complicate the biopsychosocial, spiritual, economic and contextual aspects of individuals' lives holistically from their unique perspectives (Tanhan, 2020; Tanhan \& Strack, 2020). It then initiates a transformative and critical dialogue by analyzing the factors, that is, categorizing them under large groups to facilitate understanding by collaborating with the volunteering participants and other stakeholder individuals and institutions. The second is to facilitate the lives of the participants based on the perspective of positive psychology. The third entails conducting active social advocacy by sharing the results of the analysis of the factors that complicate the lives of the participants with volunteering participants or stakeholders with the relevant individuals, institutions and organizations in contextual, real or virtual environment activities (e.g., dinner exhibition, meeting, conference, report, symposium and virtual media) with the participation of voluntary participants and stakeholders. The main objective of active social advocacy is to increase the facilitators based on the level of requirement and improve the current general well-being to effectively address and resolve the issues.

In summary, OPV is one of the qualitative research methods that aim to increase general well-being at individual and society levels and effectively address existing problems. When the OPV method is applied in cooperation with the voluntary participants and relevant individuals, institutions and organizations, in other words, employed within the context of CBPR, EST and active social advocacy, it provides more effective contextual results. Therefore, it was observed that it strengthens the participants and their communities, increases the participant resources, and the problems experienced are resolved more functionally (Tanhan, 2020; Tanhan \& Strack, 2020). Due to the limitations of innovative research during the COVID-19 pandemic, and the above-mentioned objectives and theoretical framework of the current study, the present study would provide a unique added-value for the literature.

\section{Gaps in the Literature}

The review of the studies conducted during the COVID-19 pandemic revealed that the studies on the pandemic were mostly conducted with quantitative and partially with qualitative methods. In the studies conducted with qualitative and/or quantitative methods, certain closed-ended or open-ended questions were asked to the participants and data were collected with these questions (Adnan \& Anwar, 2020; Crawford et al., 2020; Dhawan, 2020; Girik Allo, 2020; Hanuku, 2020; Mahalakshmi \& Radha, 2020; Mulenga \& Marbán, 2020; Rasmitadila et al., 2020; Tanhan et al., 2020; Tria, 2020). For example, these studies investigated the activities conducted by pre-service teachers during the pandemic (Mulenga \& Marbán, 2020), online learning experiences of college students during the pandemic (Hanuku, 
2020; Tanhan, 2020), current and future issues and trends associated with the pandemic (Tanhan, 2020; Tria, 2020), the vital role played by e-learning method in education (Mahalakshmi \& Radha, 2020), the student perceptions about online learning during the pandemic (Girik Allo, 2020), the attitudes of college students towards digital and distance education courses during the pandemic (Adnan \& Anwar, 2020), the perceptions of primary school teachers about online learning (Rasmitadila et al., 2020) and the significance and strengths, weaknesses, opportunities and challenges of e-learning (Dhawan, 2020). The review of the topics of all these studies and the employed methods/techniques demonstrated that these were qualitative studies that aimed to determine the current status.

Certain studies determined that online courses, services or research led to certain fundamental problems for many undergraduate students, such as inability to follow the course properly due to contextual and socio-economic factors, inability to complete the course due to insufficient resources, inability to submit homework and participate in the exams, and lack of available technology (Liu et al., 2020; Tanhan, 2020; Yao et al., 2020). This demonstrated that technology use should be well considered and planned in online or distance education (Tanhan, 2020; Wang et al., 2020). Certain other studies (Tanhan, 2020; Tanhan \& Strack, 2020) reported that innovative research techniques such as OPV that ask participants the positive aspects as well as the difficulties in their lives would be beneficial in research on individuals who have gone through difficult processes such as an endemic or pandemic. Since the present study employed a methodology that was not in previous studies, it could fill the gap in the literature.

\section{The originality of the present study}

Several qualitative and quantitative studies were conducted during the COVID-19 pandemic. The present study is the third study that employed OPV after the study where the method was developed by Tanhan \& Strack (2020), and adapted to Turkish language by Tanhan (2020). Furthermore, while the first study was conducted with college students in the USA pre-pandemic and the second was conducted with college students in Turkey during the pandemic to understand and advocate for their biopsychosocial spiritual and economic issues, the present study tackled a more specific issue such as understanding the factors that facilitate and complicate online education during the COVID-19 pandemic. Thus, the present study is the first study in which OPV was utilized to understand online education and it meets some important gaps. Furthermore, the authors keep collaborating with volunteer participants to develop meaningful and critical dialogues by presenting the study findings to relevant individuals, institutions and organizations via active advocacy, which was the second main objective.

\section{Method}

The present study employed the above-mentioned framework. The framework shaped all research processes, including the methodology section. The authors initially conducted a comprehensive literature review on (a) online or distance education, with a special focus on COVID-19 and whether there were any previous studies that utilized OPV and (b) empirical research on college students during the COVID-19 pandemic.

\section{Participants}

The online form employed in the present study was delivered to approximately 6000 individuals. 115 volunteer college students, lecturers and academicians completed the online form. Volunteer-based convenience sampling was employed to determine the study group. Convenience sampling entails the assignment of individuals and groups that could be easily accessed (Sönmez \& Alacapınar, 2013). Among the participants, 54\% $(n=47)$ were females and $61 \%(\mathrm{n}=53)$ were males. Out of the 115 participants, $63(54.8 \%)$ were students, $40(34.8 \%)$ were lecturers, 12 $(10.4 \%)$ were academicians. While $75(65.2 \%)$ participants owned a personal computer, $40(34.8 \%)$ did not own a personal computer. $60(52.2 \%)$ participants utilized a personal phone, $46(40 \%)$ utilized their personal computer, 8 (7\%) utilized someone else's computer, one (0.9\%) utilized someone else's phone in distance/online education.

\section{Procedure}

The authors did thorough literature review on distance or online education, OPV, and functioning of university students, teachers and academicians during COVID-19 in English and Turkish languages. Previous studies reported that college students (Tanhan, 2020) and other individuals (Tanhan et al., 2020) faced several biopsychosocial spiritual and economic issues. They proposed the employment of OPV to conduct further specific research on education during the COVID-19 pandemic. Based on all these, the Institutional Review Board (IRB) forms were prepared and IRB consent was gained to move forward. The authors collaborated with a few interested college students as partners in the study, and formed the research team from a CBPR perspective. The team discussed and decided the research process in collaboration. Following the consultation, the team developed an online form to recruit participants. 


\section{Data collection instruments: online form}

The authors developed an online form that included a consent form, IRB approval, and a few sociodemographic questions. The participants were able to watch a video, listen an audio and a written document. These documents facilitated understanding how to participate to the research. The video, audio, and the written document included the same information available on OPV and user manual for participation in the study. All documents introduced the Turkish version of the OPV and the principles for active participation in the process. The same materials different in forms facilitated participation. The materials enriched OPV participation process. Anyone with some disprivileged (e.g., low internet, lack of resources) were able to use written or audio documents rather than videos.

\section{Information for the research: consent form}

The study information and the consent form were presented to the participants. The participant had two choices (a) I voluntarily participate in the research and allow the researchers use the data I have provided and (b) I am curious about the research and want to participate but I DO NOT yet consent for the use the data I have provided in the study.

\section{Demographic information form}

In this form, the participants responded to a few questions, e.g., gender, marital status, socioeconomic status, access to a computer and the internet, and type of residence.

\section{Video documents that explained the OPV and participation}

A video on OPV was presented to the participants. The video explained (a) what OPV means and (b) how to participate in OPV research and/or activities in a more effective, meaningful, and easy way in detail. The video was developed based on a contextual COVID-19 perspective to allow the participants to easily understand OPV and participate in the process if they wish. The existence of the video also fit very well in the theoretical framework of the study. Tanhan (2020) developed English (https://www.youtube.com/watch?v=ArqgA33EMDQ) and Turkish (https://www.youtube.com/watch?v=_e0imJTtC_Y) OPV videos, and made them available for everyone interested in OPV research and/or activities.

\section{Audio documents that explained OPV and participation}

The participants were provided with an OPV audio document that explained similar issues as the video. Tanhan (2020) developed the audio document and made them available for everyone interested in OPV. The audio document works with a low or slower internet capacity and connection when compared to the video, and it is important to consider participant resources from a contextual perspective (Tanhan, 2020). Thus, participants with limited internet connection could listen to the audio document. Tanhan (2020) developed two audio documents: an English version (https://drive.google.com/drive/folders/1wtq6s4KU6zHR2uHU7ww9HJweYY_B3UiQ?usp=sharing) and a Turkish version (https://drive.google.com/drive/folders/1EDjhalb5gy_iJJXMahLR1Ye9qe1OiVy7?usp=sharing), which are both open access.

\section{Written documents that explained OPV and participation}

The participants were provided with a written document that explained the similar issues as the video and audio documents. The documents are available https://drive.google.com/drive/folders/1wtq6s4KU6zHR2uHU7ww9HJweYY_B3UiQ?usp=sharing (English version) and https://drive.google.com/drive/folders/1EDjhalb5gy_iJJXMahLR1Ye9qe1OiVy7?usp=sharing (Turkish version). Several studies stressed the importance of considering the contextual factors faced by the participants and providing tools for the disenfranchised participants (Tanhan, 2020; Tanhan \& Strack, 2020).

\section{Virtual/social media platforms}

In addition to the above-mentioned facilities, a Facebook page and a group were established to facilitate the understanding of OPV and participation by the subjects. The participants were also informed that the study findings will be available in these media. The virtual platforms were established by Tanhan (2020) and are open to all parties interested in OPV: https://www.facebook.com/groups/OPV.OSF.Online.Photovoice.Seslifoto (Facebook group) and https://www.facebook.com/OnlinePhotovoiceOPV (Facebook page). The participants and other parties interested in the OPV could use the platforms to interact with other individuals and to access the results of the present and other OPV studies. Using virtual platforms may lead to more critical and meaningful conversations (Tanhan, 2020; Tanhan \& Strack, 2020). 


\section{Online photovoice $(\mathrm{OPV})$ procedures}

The authors employed Tanhan's (2020) study and introduced five steps for an easy, effective, and fun participation. Participants were able to complete the study easily by following the steps mentioned above.

Step 1. Naming the most important facilitator and obstacle. Participants took time on thinking all possible facilitators and obstacles during the online and/or distance COVID-19 education process. Following that, the participants highlighted the most important facilitator and obstacle.

Step 2. Preparing the photos of the facilitator and obstacle. Participants prepared several photos that represented the most important facilitator and the obstacle. Participants were informed that they could take as many photos as they want and yet they could upload only one facilitator photo and one obstacle photo. The researchers explained well to the participants that to choose photos on their own perception to protect the originality of the photos. Furthermore, photos did not have to explicitly represent the factors. For instance, a participant may choose a photo of a table and it could be the most representative of online education for a participant, while a photo of the sky can could be one of the most representative of distance education. Representation was based on participant perceptions.

The documents (video, audio) that were provided by Tanhan (2020) for OPV use explained how participants could improve their participation process and enrich their stories, photos, and themes when they follow the documents. Furthermore, the researchers explained to the participants to use non-copyrighted photos or drawings available for public use. Thus, the participants could, though not encouraged, use any non-copyrighted photos that were available online for all people. In OPV approach, it is need to consider a contextual perspective to understand disenfranchised populations (Tanhan, 2020; Tanhan \& Strack, 2020).

Step 3. Uploading photos and stories. At step three, the participants reflected on previous steps one and two and decided which photos to upload one for the facilitator and one for the obstacle. Following that, the participants went through GÖZSAN (SHOWED in English) acronym, which we is explained in the following lines. In this way, the acronym facilitates a more effective and succinct caption. (Tanhan, 2020). The researchers explained to the participants that they could choose to follow SHOWED for a more effective and fluent caption. In OPV, participants are encouraged to write a thorough and effective story so that readers and any others interested in the subject can see the subject from their perspective (Tanhan, 2020).

In this third step, participants followed the acronym so that they were able to write a meaningful and enriched paragraph. Tanhan (2020) carefully edited SHOWED questions from English to Turkish and called it GÖZSAN-an acronym similar to SHOWED so that the participants can complete their stories easily and with more fun. GÖZSAN acronym consists of six questions. The questions are below. In Turkish "GÖZ" means "the eye or person" and "SAN" means "to assume;" and thus, Tanhan (2020) explained that if people follow GÖZSAN, other people (eyes/GÖZ) will not assume (SAN) various messages from the participants' conveyed messages. In other words, following GÖZSAN is more likely to prevent others assuming something very different from the participants' desired messages. In light of all these, Tanhan (2020) strongly suggested researchers and participants to consider GÖZSAN during writing their captions. The current authors also reminded the participants to pay utmost attention to keep the acronym in mind when writing and submitting their message to be much more effective and contextual with an original story.

SHOWED acronym could be explained as follows:

S: What do you SEE in the picture that represents a facilitator (strength, support) for you or your community in the online and/or distance education conducted during COVID-19 pandemic? What do you SEE in the picture that represents an obstacle (concern, issue) for you or your community in the online and/or distance education conducted during COVID-19 pandemic?

$\mathrm{H}$. What is HAPPENNING in your picture? (Briefly describe the picture).

O. How does that relate to (Y)OUR life as an individual and/or community?

W. WHAT contributes to or creates the facilitator (support, strength) and what are the causes or creators of the obstacle (concern, issue, problem)?

E. What did you EXPERIENCE (feelings, thoughts, sensations, behaviors) when you took the photo and when you wrote the caption and when submitted the photo?

D. What can we (as educators, researchers, mental health professionals, peers, university staff, etc.) DO about it? 
Step 4. Coming with at least one or at most three themes or metaphors for the facilitator and obstacle. In this fourth step, the researchers told the participants to take time to consider the first three steps and produce at least one or at most three themes or metaphors. Themes or metaphors facilitate others to understand participant photos and stories effectively. The participants were recommended to use at least one or at most ten words to express one to three metaphors or themes.

Step 5. The participants attributed the facilitator and the obstacle to one or more levels of EST using a multiple choice question. The researchers asked the participants to associate the facilitator and the obstacle to one or more levels of EST. Tanhan (2020) was the first and the present study is the second OPV study, where the researchers included this step to understand how the participants attribute the factors to EST levels.

The participants first completed this first five steps for the most important facilitator and then they completed for the most important obstacle. In this way, the participant starts with something positive (facilitator) and then something that they may not enjoy, and this order seems to be more protective and effective from a mental health perspective (obstacle) (Tanhan, 2020; Tanhan \& Strack).

Analyses: Online interpretative phenomenological analysis (OIPA)

Online Interpretative Phenomenological Analysis (OIPA) was employed in data analysis. OIPA includes five steps: (1) checking photos, captions, and the consent form for missing information, (2) investigating submitted data (e.g. photos, captions), (3) categorizing the facilitator themes, (4) categorizing obstacle themes, and finally (5) investigating the association of the themes and EST levels by the participants' responses. Please refer to Tanhan (2020) for more detailed information for each step.

\section{Findings}

Table 1. Main themes on the facilitators of online education during the COVID 19 pandemic

\begin{tabular}{|c|c|c|c|c|}
\hline & \multirow[t]{2}{*}{ Main Themes } & \multirow[t]{2}{*}{ Participants } & \multicolumn{2}{|r|}{ Total Participants } \\
\hline & & & $\%$ & 115 \\
\hline 1 & Technology & $\begin{array}{l}\mathrm{P}_{7,11,13,14,19,21,22,23,24,25,26,27,29,43,46,53,57,59,65,70,71,83,85,86,89,90} \\
, 100,102,103,108,114\end{array}$ & 35 & 31 \\
\hline 2 & Internet & $\begin{array}{l}\mathrm{P}_{3,14,15,17,19,21,23,25,26,43,46,57,59,65,69,70,78,85,86,89,90,91,101,} \quad 102, \\
103,108,110,111\end{array}$ & 32 & 28 \\
\hline 3 & Communication & $P_{24,25,44,46,51,59,65,71,73,75,84,93,97,100,103,104,107,109}$ & 20 & 18 \\
\hline 4 & Emotion(s) & $P_{9,11,13,17,18,36,44,46,48,51,56,63,73,75,79,83,89}$ & 19 & 17 \\
\hline 5 & Economy & $\mathrm{P}_{9,13,17,29,35,36,48,61,63,66,69,76,78,79,86,92}$ & 18 & 16 \\
\hline 6 & Nature and space & $\mathrm{P}_{9,11,73,76,78,92,96,105,108,112}$ & 11 & 10 \\
\hline 7 & $\begin{array}{l}\text { Experience and } \\
\text { knowledge }\end{array}$ & $\mathrm{P}_{18,23,27,34,48,69,96,113,109}$ & 10 & 9 \\
\hline 8 & Equal opportunity & $\mathrm{P}_{13,40,61,67,77,80,92,104,112}$ & 10 & 9 \\
\hline 9 & $\begin{array}{l}\text { The difference } \\
\text { between online and } \\
\text { distance education }\end{array}$ & $\mathrm{P}_{2,15,29,42,97}$ & 5 & 5 \\
\hline 10 & Tools and equipment & $\mathrm{P}_{16,17,18,52,113}$ & 5 & 5 \\
\hline 11 & Responsibility & $P_{26,49,52,67,109}$ & 5 & 5 \\
\hline 12 & Social media & $\mathrm{P}_{32,56}$ & 2 & 2 \\
\hline 13 & No theme & $\begin{array}{l}P_{4,6,10,20,28,30,31,33,35,38,39,45,47,54,55,58,60,68,74} \\
82,94,95,99,106,115\end{array}$ & 28 & 25 \\
\hline 14 & No story or theme & $\mathrm{P}_{5,12,41,64,72,88,98}$ & 8 & 7 \\
\hline
\end{tabular}


Three examples of photographs and related stories on the facilitators of online or distance education during the COVID-19 pandemic are presented below:

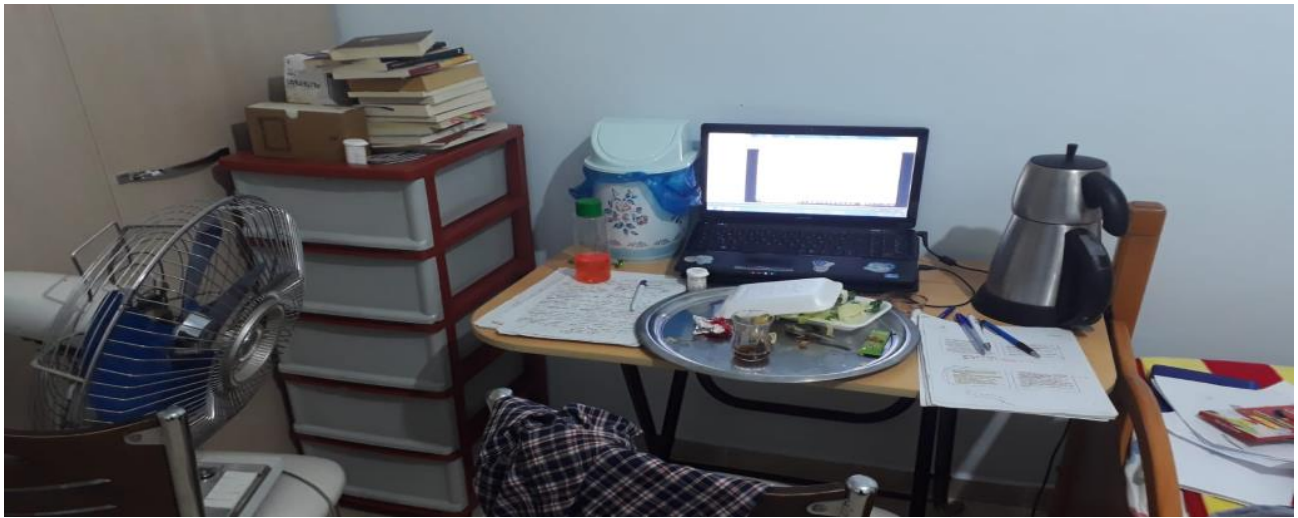

Photograph 1. Sample factor 1 that facilitates distance/online education according to participant P10

"The most facilitating factor in the distance education process we experienced for the first time was the supportive and solution-oriented approach of the school administration and our communication with colleagues to conduct a better education. Computer photo represents online communication. The environment where I took the photo represents the feeling of peace and security that I felt in that environment. I think that the communication factor affected the performances of the teachers in this process. Observing the comprehension and constant feedback is motivating in distance education because it is difficult to maintain motivation when compared to face-to-face education. In my opinion, the school culture that prioritizes education and students led to this facilitator. Right now, I realize that I thought about advantages of the process for the first time, it was good for me to realize this. I think that solution and trust-based communication should be the principle in facilitating distance education" (P10).

Themes: "Technology, internet, communication, a peaceful environment, producing solutions."

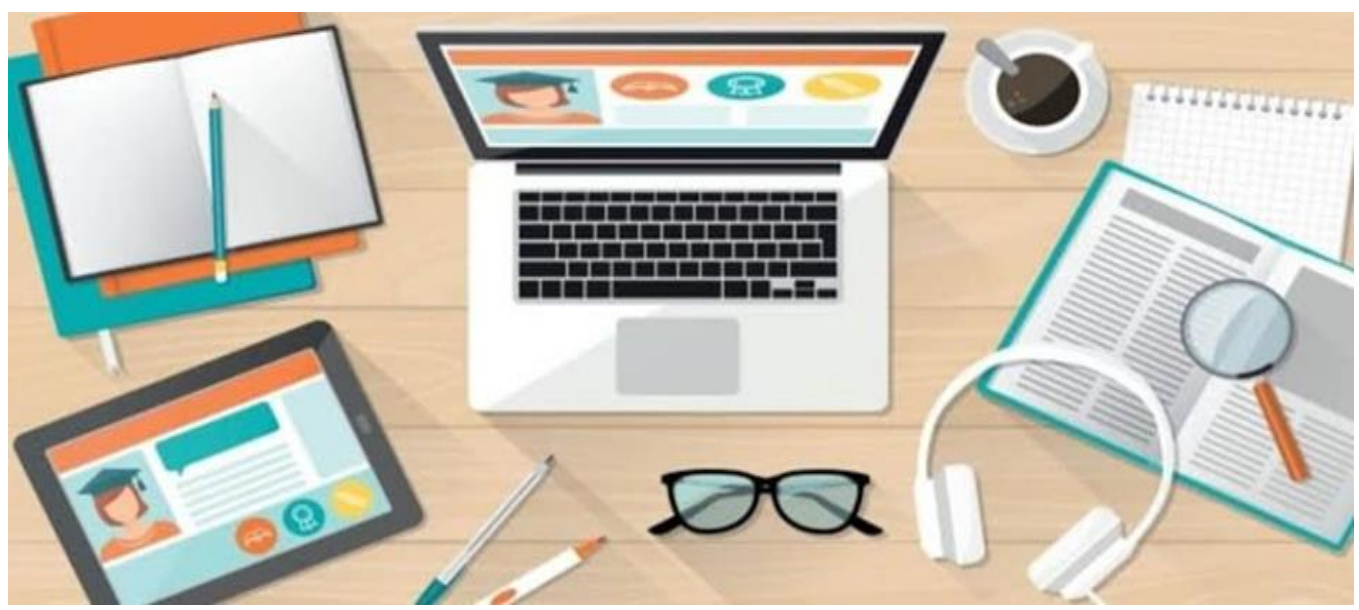

Photograph 2. Sample factor 2 that facilitates distance/online education according to participant P25

"This photo included devices such as tablets, computers, smart phones, individuals participating in distance education, and course material such as books, notebooks and pencils. The focus of the photo was on individual requirements to access distance education and the devices required to provide and conduct distance education during the COVID-19 pandemic. In this process, the main factors that facilitated distance education included electronic devices such as smart phones, computers, tablets, and the individuals who participated in internet and distance education. The COVID-19 pandemic led to several changes in our personal and social lives. One of these changes was observed in education. The photograph includes a novel way and method employed in education and instruction. This photo also reflects me, as a teacher and a learner, who has always been involved in education. It could be suggested that COVID-19 
pandemic accelerated the development of distance education with the help of current technological advances and led to the creation of this facilitator. When selecting this photo, I imagined the difficulties encountered during the education process we experienced in the near past. Switching to the distance education without prior preparations, the required infrastructure and facilities introduced several problems. Thus, infrastructure could be strengthened, internet access could be extended to every region, and an education portal could be developed to provide easy and inexpensive access for the students" (P25).

Themes: "Internet access, technological devices, individual and distance education."

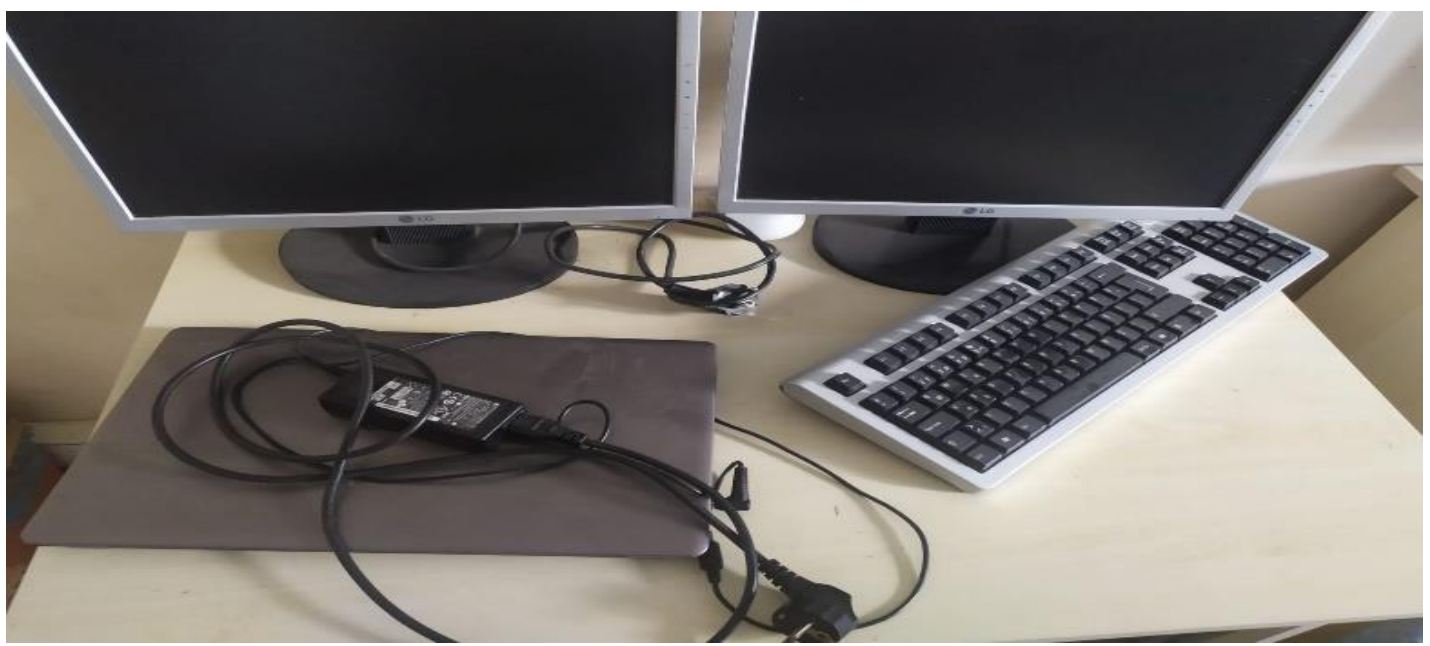

Photograph 3. Sample factor 3 that facilitates distance/online education according to participant P23

"During the COVID-19 pandemic, I observed that a good computer, phone and unlimited internet were the most important factors that facilitated distance education. Especially a large computer memory, a good camera and unlimited internet were the factors that facilitate distance education in my opinion. During the COVID-19 pandemic, it is important for individuals to use their computers in distance education. The photo I selected includes two desktop computers and a laptop computer. In my case, I had to connect with another computer when there was a problem in one. I was happy because I could conduct the course(s) with my computer, in particular since I could fulfill my responsibilities, and in general, I could provide the necessary knowledge and achievements to my students during the semester, and thus, could initiate a social interaction and exchange of information. Currently, as I write these words, the major responsibility falls on the institutions in distance education, also, the instructor who conducts distance education should take responsibility to use the technology and inform the students. In addition, I think for the students to benefit from distance education, computers, tablets, etc. should be provided by the Council of Higher Education, MoNE, or the university. Because an individual from a village without a computer, tablet, etc. and economic means could not benefit from education without technological means and limited or unlimited internet. Therefore, all of these should be taken into account when conducting distance education. In addition, I would like that a trial exam should be uploaded to the system before the actual exam. Thus, students, teachers and academicians should have necessary technological tools for a functional distance education. Furthermore, unlimited internet should be available. Even when unlimited internet is not available, it is necessary to provide unlimited access for the distance education system utilizing the university access system. In addition, the academicians should pay attention to the resources of the information they use in presentations. In addition, the parents should also be sensitive to certain issues. Otherwise, it will not be possible to prevent information pollution. Because lending a slide to a teacher instructing in another university would make the latter a free-rider" (P23). 
Themes: "Technological tools (computer, tablet, smart phone), unlimited access and technological knowledge"

Table 2. Main themes on the obstacles to online education during the COVID 19 pandemic

\begin{tabular}{|c|c|c|c|c|}
\hline & Main Themes & Participants & $\%$ & $\begin{array}{l}\text { Total } \\
\text { Participants } \\
115\end{array}$ \\
\hline 1 & Technological problems & $\begin{array}{l}P_{17,18,19,20,21,24,25,26,27,29,30,31,32,33,34,37,38,39,40,43} \\
47,48,49,57,61,71,74,75,76,78,80,84,86,89,92,94,96,97,100,105,111\end{array}$ & 47 & 41 \\
\hline 2 & Internet problems & $\begin{array}{l}\mathrm{P}_{11,19,20,21,22,23,24,25,26,27,28,29,31,32,33,34,38,39,41,48,49,51,54,55,59,61} \\
, 62,70,83,84,85,89,90,94,97,99,102,111,113,115\end{array}$ & 46 & 40 \\
\hline 3 & Inequality of Opportunity & $\begin{array}{l}\mathrm{P}_{18,20,22,25,28,29,30,33,37,40,41,42,43,48,49,50,51,52,53,54,61,66,69,70,73,75} \\
, 76,78,83,85,97,99\end{array}$ & 36 & 32 \\
\hline 4 & $\begin{array}{l}\text { The difference } \\
\text { online and } \\
\text { education }\end{array}$ & $\mathrm{P}_{10,17,21,29,39,42,43,45,57,59,66,73,74,76,80,83,86,92}$ & 20 & 18 \\
\hline 5 & $\begin{array}{l}\text { Lack of interaction/ } \\
\text { communication }\end{array}$ & $\mathrm{P}_{7,15,16,22,24,36,46,52,53,55,68,84,91,96}$ & 16 & 14 \\
\hline 6 & Inexperience & $P_{8,9,13,14,16,17,26,37,46,57,74,105}$ & 13 & 12 \\
\hline 7 & Future/uncertainty & $\mathrm{P}_{44,56,62,63,69,71,74,87,93,108,109}$ & 12 & 11 \\
\hline 8 & Monotony & $\mathrm{P}_{23,31,45,73,74,89,92,97}$ & 9 & 8 \\
\hline 9 & Emotion(s) & $\mathrm{P}_{65,68,69,91,104,108}$ & 6 & 6 \\
\hline 10 & Unproductivity & $\mathrm{P}_{6,15,16,45,46}$ & 5 & 5 \\
\hline 11 & Nature and universe & $\mathrm{P}_{2,3,112,114}$ & 4 & 4 \\
\hline 12 & No theme & $\mathrm{P}_{4,60,64,79,101,103,106,107}$ & 9 & 8 \\
\hline 13 & No story or theme & $P_{5,12,35,57,67,72,81,82,88,95,98}$ & 12 & 11 \\
\hline
\end{tabular}

Three examples of photographs and related stories on the obstacles to distance education during the COVID-19 pandemic are presented below:

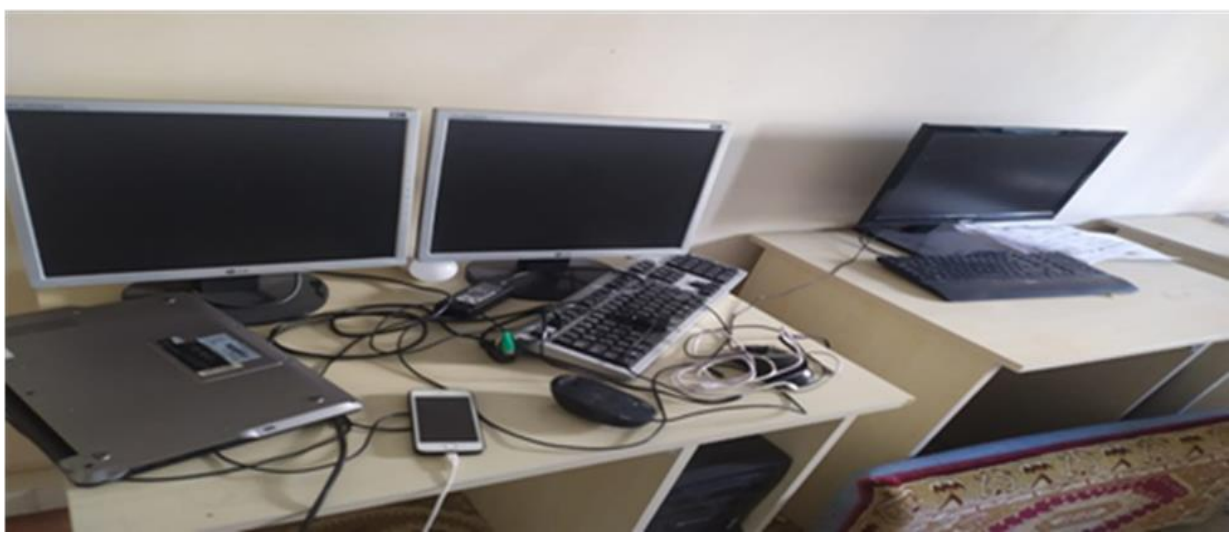

Photograph 4. Sample factor 1 that complicates distance/online education according to participant P26

"In my opinion, the most important factor that complicate distance education during the COVID-19 pandemic is the lack of technological resources such as computers, tablets, etc., and the upload/download of several course videos with limited internet connections. The limited internet is a more serious problem since it prevents the student to listen to the lecture. There are several problems for instructors and students in distance education. These also differ between students and instructors. For example, a student may have a computer, but distance learning could be challenging due to the eyesight of the student. Another student may not have a computer and internet due to economic problems. Another student may not focus on the course since there is no interaction. These problems are among several factors that complicate distance education for the students. For the instructors, problems such as the development of slides for several 
courses, shooting videos for several hours and uploading these videos on YouTube, etc., and the publication of these info the media, etc. make distance education difficult." (P26)

Themes: "The lack of technological tools and limited internet access"

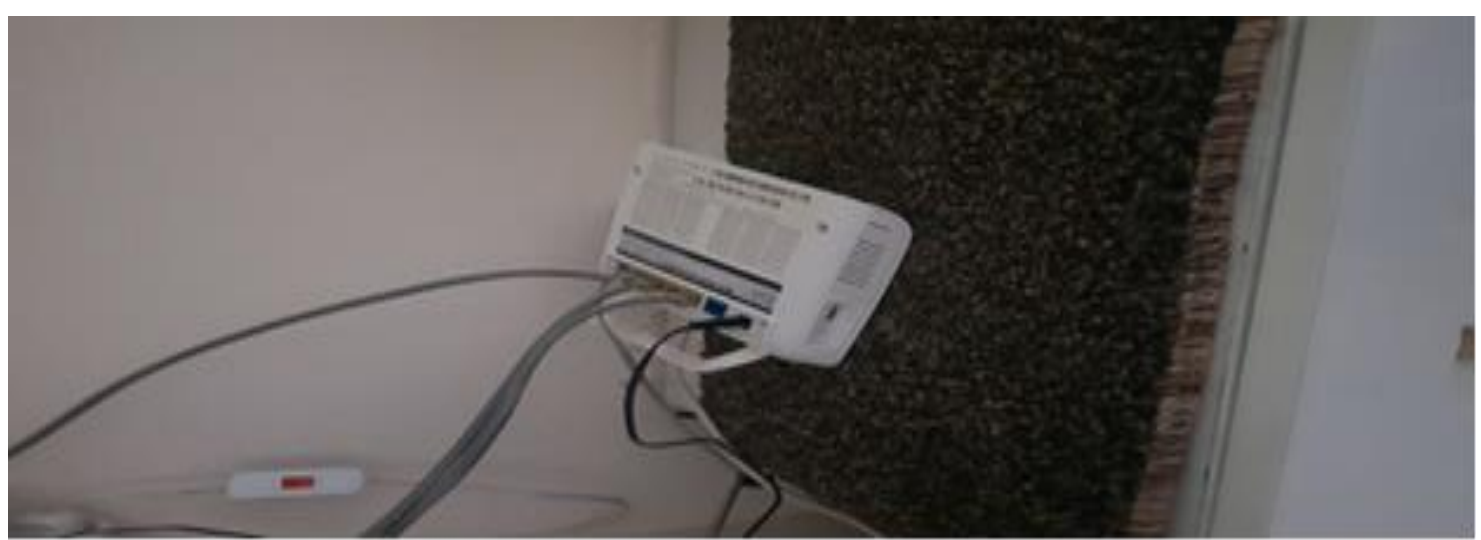

Photograph 5. Sample factor 2 that complicates distance/online education according to participant P36

"The current means of access to distance education is the internet. Although a phone or a computer seems to be sufficient for access to the Internet, the performances of the two are different. In this process, the main problems I and my friends experience include inadequate internet and the insufficiency of smart phones in certain assignments. Although this issue was mentioned in classroom groups, homework was assigned based on the requests of the lecturers and the majority. I selected a modem in my picture to draw attention to the importance of unlimited internet. When adequate infrastructure is available, distance education may turn into an advantage, but this is not possible currently" (P36).

Theme: "Internet access."

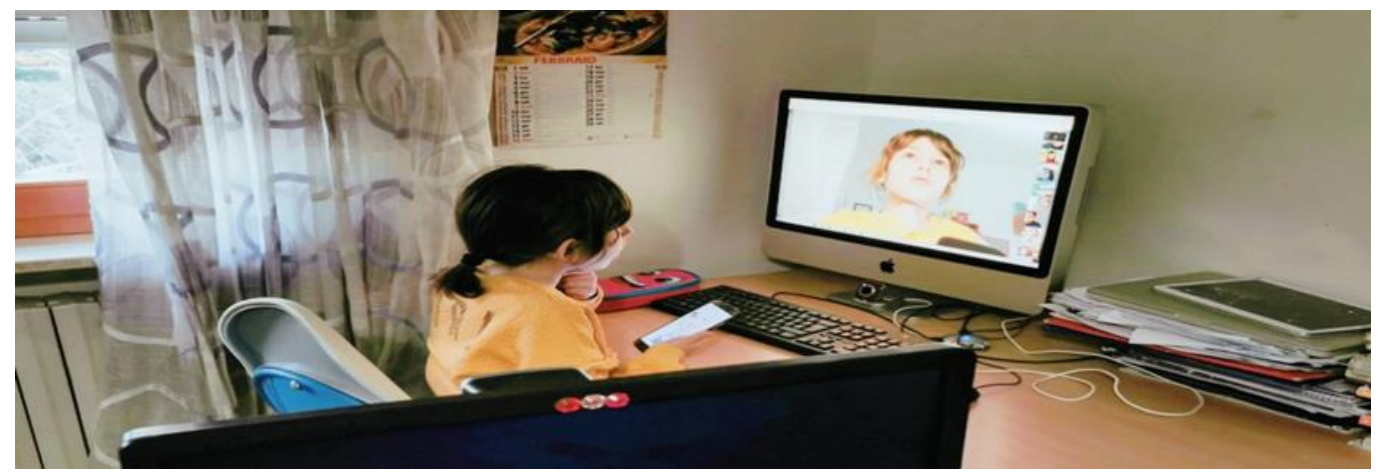

Photograph 6. Sample factor 3 that complicates distance/online education according to participant P12

"The challenging factor in distance education was the internet problems. There was no internet network in our house. And my own internet package was limited, I did not have the opportunity to watch the videos sent by my colleagues. I tried to download the submitted documents and work with these. Of course, reading was not sufficient, it would be much better to hear the views of our esteemed professors in the videos as much as in in the classroom. In the photo, you can see technological devices such as a phone, a computer and a Wi-Fi symbol. Everyone in our house has a phone, and there is a computer (not mine). There are several tools, but when there is no internet, sometimes even these do not make a difference. Frankly, when I looked at the photo, I felt awkward. Even before distance education, I was constantly thinking about how to study without internet. And my brain was overworked already. But luckily, we somehow got through this process. In such a process, education was necessary, but the internet, the point of access to knowledge, was not considered. I am sure there were also those who were worse off than me. For example, students living in the villages. Assistance should have been provided for many students" (P12). 


\section{Theme: "Internet problem"}

Table 3. The attribution of the facilitating and complicating factors to the levels of EST

\begin{tabular}{lllll}
\hline The attributed system and factors & Personal & Microsystem & Exosystem & Macrosystem \\
\hline Facilitating factors & $97(\% 84,3)$ & $52(\% 45,2)$ & $41(\% 35,7)$ & $39(\% 33,9)$ \\
Complicating factors & $79(\% 68,7)$ & $68(\% 59,1)$ & $49(\% 42,6)$ & $51(\% 44,3)$ \\
\hline
\end{tabular}

The review of Table 3 demonstrated that the first ecological factor that facilitated distance/online education for the participants in the COVID-19 pandemic was individual/personal, the second was the microsystem, the third was the exosystem, and the fourth was the macrosystem factor. Most ecological systems entailed personal participation, inadequacy or lack of technological tools such as personal computers etc. Furthermore, the first ecological factor that complicated distance/online education during the COVID-19 pandemic was personal, the second was the microsystem, the third was the macrosystem, and the fourth was the exosystem factors. An overall analysis would demonstrate that the factors that facilitated or complicated distance education during the COVID-19 pandemic originated from the individual, institutional and organizational systems.

\section{Discussion, Conclusion, and Recommendations}

The virus affected the whole world within a short period of time (Huang et al., 2020). The virus led to serious and unexpected financial and moral problems (Tanhan et al., 2020). During the COVID-19 pandemic, people developed several behavioral problems (Cortese et al., 2020) and unpleasant emotions, thoughts and physical sensations such as boredom, aimlessness education related issues, conflicts with parents and educators, burnout with technology and psychopathology (e.g., depression, anxiety, sleep issues, post-traumatic stress disorder symptoms, intolerance to uncertainty, sleep issues, obsession with cleaning and news) to name a few (Tanhan, 2020). Based on the present study findings, online education did not provide equal opportunities, students were exposed to the lack of technology and access limitations in online educations, and the parents were not well-informed about online education. In addition to all these problems, it was concluded that student and educator study participants also experienced psychological and social problems.

\section{The main themes that facilitated distancelonline education during COVID-19 pandemic}

The main themes that facilitated online education during the COVID-19 pandemic and their frequencies are ranked as follows in the study: technology $(35 \%, \mathrm{n}=31)$; internet $(32 \%, \mathrm{n}=28)$, emotion $(\mathrm{s})(19 \%, \mathrm{n}=17)$, communication $(20 \%, \mathrm{n}=18)$, economy $(18 \%, \mathrm{n}=16)$, nature and space $(11 \%, \mathrm{n}=10)$, experience and knowledge $(10 \%, \mathrm{n}=9)$, equality of opportunity $(10 \%, \mathrm{n}=9)$, difference between online and distance education $(5 \%, \mathrm{n}=5)$; equipment $(5 \%$, $\mathrm{n}=5)$, responsibility $(5 \%, \mathrm{n}=5)$, and social media $(2 \%, \mathrm{n}=2)$.

It was determined that the factors that facilitated online education were mainly dependent on technological and internet infrastructure during the pandemic. According to Allen et al., (2002), distance education could allow students to learn a subject based on individual differences. The review of the facilitating factors determined in the study revealed that online education provided "equal opportunity" to the students. Based on these findings, it was determined that online education provided important opportunities to students and educators/academics. According to some researchers (Lack, 2013; Tanhan, 2020; Wu (2015), distance/online education could be as effective as face-to-face education. Based on the findings of the above-mentioned studies, for an effective distance/online education when compared to the face-to-face education, technological and internet infrastructure should be adequate. Tanhan (2020) found in their OPV study during the pandemic that $\% 10$ ( $\mathrm{n}=13$ out of 127) of the participants reported online education and technology as the most important facilitator for their life and most of them preferred online education to face-to-face primarily for saving time and allowing them to listen the courses again at their convenience. The review of the studies on distance/online education and learning (e-learning) demonstrated that the success of online learning was associated with the quality of education, its quality when compared to face-to-face education, the online education infrastructure of an institution or organization, etc. (Alexander \& Golja, 2007; Bliuc et al., 2007; Coates et al., 2005; Lester \& King, 2009; Lee \& Lee, 2008; Lee et al., 2009; Levy, 2007; Tanhan, 2020). Lee (2010) reported that the quality of online education depends on the development level of the nation and the competency of the online education instructor. Furthermore, the awareness of the parents should be raised on distance/online education. For example, participant P10 emphasized this issue: "My parents need to remember that I am a student and convinced that being online does not mean I do not attend the classes." Distance/online education allows students to participate in the class, as well as learning based on their interests and needs, which helps with getting social. For example, the statements by P42 that "the students had the opportunity to put prior knowledge into 
practice about the sample question that all participated and could comment," and by P17 that "students could provide instant feedback since they were curious about something at that moment, and when students see their friends and teachers in an environment that they are accustomed to, their active participation improves" supported the study findings. Similarly, Tanhan (2020) also found most of the participants (\%26) complained about not being able to socialize due to home confinement and thy found online education as part getting socialized.

The factors such as the quality, flexibility, sensitivity of online education, communication and technical support services, etc. positively affect student perceptions about online education (Helgesen \& Nesset, 2007; McGorry, 2003; Rovai, 2003; Tanhan, 2020). Thus, it was concluded that online education provides equal opportunity for the students if the resources are equally distributed. The present study findings revealed that student perceptions about online education depended on the availability of a robust technological infrastructure and free internet access. This finding was consistent with the study by Paechter \& Maier (2010) and Tanhan (2020), who reported that student perceptions about online learning was positive. Furthermore, some other researchers (Haines et al., 1986; Diekhoff et al., 1996; Stiles et al., 2018; Tanhan, 2020; Vandehey et al., 2007) reported that certain difficulties were experienced in face-to-face training as well. For example, in Tanhan (2020) study, some students reported that through online education process they have realized that they waste most of their resources in terms of time, money, energy during pre-pandemic face-to-face education. Thus, when technological infrastructure and internet are free in distance/online education, it would be facilitated and especially the attitudes of college students and instructors towards online education would improve. Because, after a certain age and certain courses are instructed with distance/online education, it is more likely that online education to save students time and money. Most study participants held that view.

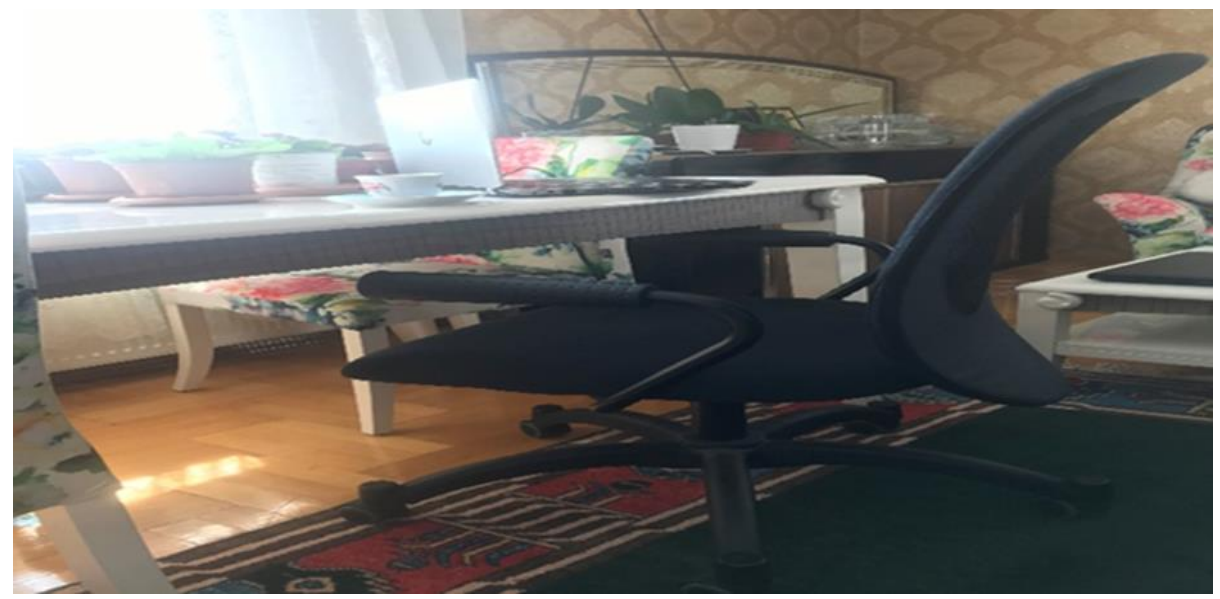

Photograph 7. A visual on the main themes that facilitated distance/online education according to participant P9

"In a big city like Istanbul, it is necessary to leave home a few hours before the class to arrive at the physical classroom. Before, there was a preparation process that involved ironing, dressing, etc. In online education, it is often enough to be next to your computer in a comfortable corner of your home 5-10 minutes before the class. [...]. It is more comfortable, more laid-back, it reduces worries such as 'Could I be at the classroom on time? Is there traffic?' and contributes to focus on the course. Initially, online education could be available at least in courses or departments that do not require physical attendance even at a certain rate, provided that far-away students also have internet access; more accessible and less expensive education may be possible for those who cannot attend a good university in a big city due to financial difficulties. Travel, accommodation and food expenses could be saved and spent on a quality computer that could be used in education" (P9).

Based on the views of the participant P9, it could be suggested that distance/online education could be an advantage.

"When compared to rushing to school in early morning hours, taking busses with 250 people, and missing the classes in several days, UZEM-based classes save time and money when I take the classes online. I am in another day of distance learning during the pandemic. I attend live classes based on my university education weekly course schedule. I follow the UZEM courses from my desk in my own room, I listen to the teacher and take my notes." (P32). 
Another important advantage of distance/online education was to make students aware of their own skills and capabilities by making them think about their inner world. "I think that the factor that facilitated distance education during the COVID-19 pandemic was personal contributions. [...] we were more oriented towards our inner world, and we spared time to spend with ourselves and were isolated from other people." (P36). Thus, the perceptions were positive about distance/online education during the COVID-19 pandemic. According to Tanhan (2020), "mindfulness" (33\%, $\mathrm{n}=42$ out of 127), spirituality $(18 \%, \mathrm{n}=23)$, and "online / distance education" $(10 \%, \mathrm{n}=13)$ were among the most important factors that made the life easier for college students during the COVID-19 pandemic. Thus, it could be suggested that the COVID-19 pandemic allowed the students to focus on their inner world and conduct easier lives thanks to distance/online education.

Another significant study finding was the capability to upload several documents to the system in distance/online education. The study findings revealed that another important factor that facilitated distance/online education was the benefits of the tools, materials, and innovative instructional methods. These findings were related to augmented reality. According to Ersoy et al. (2016), instructional activities conducted with augmented reality have quite positive effects on students when compared to other computer-aided instruction applications. Tanhan (2020) and Tanhan and others (2020) also found online mental health and online educational activities that were hybrid meaning requiring people to attend in some online groups, such as Online Read-Reflect-Share (ORRS) bibliotherapy, while doing most of the activity offline at their convenience to be very affective and facilitative. Augmented reality applications allow the students to improve their experiences especially in applied courses in higher education institutions, conduct virtual field trips, develop assessment images in field trips, or attending courses simultaneously instructed by faculty members in different universities (Erbaş \& Demirer, 2015), leading to more effective applied course instruction. Previous studies demonstrated that courses instructed with augmented reality applications allow easier learning of the topics by learners (Abdüsselam \& Karal, 2012; Kaufmann, 2003; Özarslan, 2013; Shelton \& Hedley, 2002; Sirakaya, 2016). Thus, the employment of augmented reality in distance/online education will improve the productivity of the students in courses and education. The employment of augmented reality to improve language skills such as reading, comprehension, listening and speaking would improve the quality of distance/online in language instruction. The most important factors that facilitated distance/online education in the COVID-19 pandemic were the technological infrastructure and free internet. The most important requirement for augmented reality is a robust technological infrastructure. When technological infrastructure and internet access are available for everyone, the main theme of "emotions", one of the important facilitating factors determined in the study, will positively come to the fore. Because due to positive emotions such as satisfaction, joy, motivation, etc. with distance/online education, the views and perceptions of the students can improve.

The study findings demonstrated that another facilitating factor was online nature of the courses. Certain participants found online courses more beneficial when compared to distance (uploading videos, open education) education during the COVID-19 pandemic. According to the participants, online courses were more advantageous when compared to distance education (open education, video courses) since they provide interaction with the course instructor, immediate responses to their questions, and ability to ask questions when they could not comprehend a topic. Distance education (open education, video courses) has disadvantages in instant answers or asking questions, etc. In terms of situations, it is at a disadvantage compared to online education. The participants who noted that "unlimited internet, fast online access" (P3), "live courses could be conducted to facilitate distance education" (P30) mostly believed that the courses should be conducted online rather than distance education. In the present study, one of the main themes on facilitators and obstacles to distance/online education during the COVID-19 pandemic was "the difference between online education and distance education". While the videos or other documents are uploaded in distance education, the students do not need to have internet access, and students have the opportunity to watch the videos and read other documents uploaded by the instructor later on. The student attendance is known in online/live courses. Furthermore, students who did not understand the topic could ask questions to the instructor when they attend the online course and could receive immediate feedback on the topic. However, in distance education, videos, PDFs, WORD files, visuals and various other documents are uploaded to the system and students take the course using these documents at a later time. The study participants stated that online education was more efficient when compared to distance education, and the student and the instructor/teacher were better at maintaining healthy communications. However, constant internet access requirement and compulsory attendance complicate online education.

Another prominent theme was communication in the study. In distance/online education, the communication between students and instructors and academicians is conducted on applications such as WhatsApp, Messenger, E-mail, Facebook, and Instagram, facilitating distance/online education. Because, the solution for the problems 
experienced by students or instructors/academics in distance/online education process have been determined by experts. Kirby (1999) reported that interaction between teachers and students is improved in distance and online education. The fact that communication, one of the main themes determined in the present study, was a facilitating factor in distance education in the COVID-19 pandemic was consistent with the findings reported by Kirby (1999) and Tanhan (2020). In Tanhan (2020) study during the pandemic, $2 \%$ of the participants reported having faculty members with empathy to be one of the most important facilitators for their life. Overall analysis of the present study findings suggested that the facilitators were consistent with the principle of equal opportunity in education. It is an indispensable method for students who could not take any conventional courses to take various courses in distance/online education.

\section{The main themes that complicated distancelonline education during COVID-19 pandemic}

The study findings demonstrated that the frequency distribution of the main themes that complicated the distance/online education during the COVID-19 pandemic was as follows: technological problems $(47 \%, \mathrm{n}=41)$, internet problem $(46 \%, \mathrm{n}=40)$, inequality of opportunity $(36 \%, \mathrm{n}=32)$, difference between distance and online education $(20 \%, \mathrm{n}=18)$, non-interaction/non-communication $(16 \%, \mathrm{n}=14)$, inexperience $(13 \%, \mathrm{n}=12)$, future/uncertainty $(12 \%, \mathrm{n}=11)$, monotony $(9 \%, \mathrm{n}=8)$, emotion(s) $(6 \%, \mathrm{n}=6)$, nature and universe $(4 \%, \mathrm{n}=4)$, and unproductivity $(5 \%, \mathrm{n}=5)$.

The review of the main themes determined in the study that complicated distance/online education in the COVID-19 pandemic revealed that the prominent themes were related to technological problems, internet access, and the lack of infrastructure. College students $(21 \%, \mathrm{n}=27$ out of 127) as the participants reported that facing difficulties with online or distance education to be one of the most critical obstacles during their life in the pandemic process (Tanhan, 2020). Alexander and Golja (2007), Bliuc et al. (2007), Coates et al., (2005), Lester and King (2009), Lee and Lee (2008) Lee et al. (2009), and Levy (2007) reported that online learning was associated with the quality of education and the online education infrastructure of the institution or organization. Thus, conducting distance/online education on a system with insufficient technological infrastructure would lead to inefficient education for the students. Even when the technological infrastructure is available, unlimited internet access is required for distance/online education. The first two main themes that complicated distance/online education according to the participants during the COVID-19 pandemic were the lack of technological infrastructure and internet access, or connecting to distance/online education services with limited internet access. This led to problems experienced by the students in distance/online education during the pandemic.

Another major theme that complicated distance/online education during the pandemic was inequality of opportunity. The study findings revealed that there was inequality of opportunity in the online/distance education measurement and evaluation exams since certain students did not own computers, smart phones, etc. due to economic hardships or those lived in rural areas could not access the internet. This finding fits with Tanhan (2020) and Tanhan and others' (2020) studies conducted during the pandemic. The review of the participant statements that "I think the most important factor that complicated distance education was the exams. Taking the exam on the system introduced certain problems in writing and limited time" (P14), "the lack of face-to-face interaction, problems with reliability and validity of the exams" (P16), "the most important factor that negatively affected us in the process was the internet problem. We faced this problem during the exams and in class participation" (P28), "systemic distress (the system removed certain exams, recorded as unattended although we took the exam)" (P47), "we encountered various uncertainties during the distance education process. This led to uncertainties especially in the exams. Due to our department, our exams are mostly based on writing and comments, so we experienced some technological difficulties. We encountered problems such as time constraints, inability to use technological devices, and inability to complete the exam due to the interruption of the internet connection. To solve these problems, internet should be provided for every student" (P54), “... students easily answer the exam questions by cheating, and I do not think it is a healthy process. [...] It is difficult to conduct Arabic language exams online" (K97) demonstrated the serious problems in measurement and evaluation in distance/online education during the COVID-19 pandemic. It was determined that this problem varied between the departments and the students. 


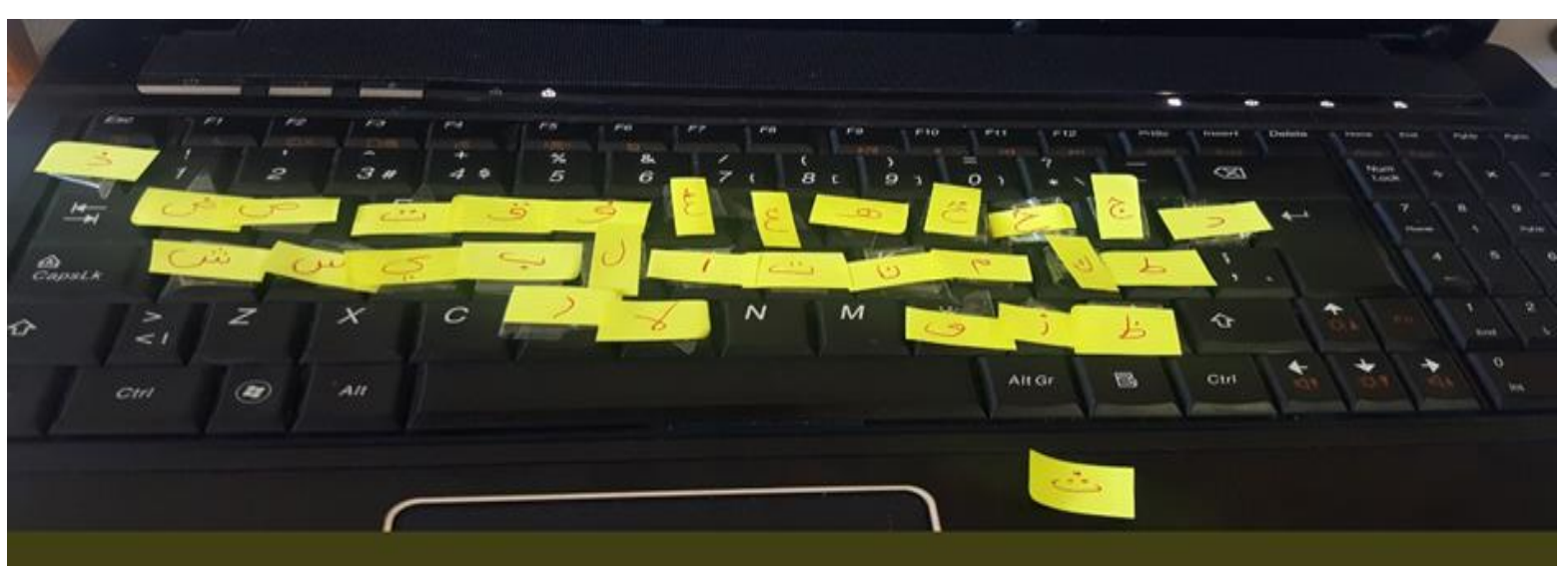

Photograph 8. A visual on the main themes that complicated distance/online education according to participant P97

According to Jung and Yeom (2009) and Ramu and Arivoli (2013), the security could not be provided adequately due to the distance between teachers and learners in e-exams. The factor of security could be achieved by improving the technological infrastructure in measurement and evaluation in distance/online education and providing related training and seminars for the students and educators (teachers, academicians). Bozkurt and Uçar (2018) concluded that biometric and information-based identity verification methods would be more reliable in online assessment and evaluation exams. McGorry (2003) reported that quality in measurement and evaluation depends on several variables. Based on the above-mentioned statements, the required online security measures should be taken in addition to a robust technological infrastructure to ensure equal opportunity in distance/online education measurement and evaluation.

The study findings revealed inequality of learning opportunity, the third main complicating theme for online/distance education, was associated with both measurement and evaluation and various socio-economic attributes of the students. The participants stated that they tried to use electronic devices such as technology, computer, internet and telephone for the course; however, they experienced certain fundamental problems and distance/online education was challenging. Certain participants stated that they either had very limited or no resources required by distance/online education. Previous studies also concluded that online lectures, services or research could lead to some fundamental problems for several undergraduate students, such as inability to fully follow and understand the course due to contextual and socioeconomic factors, and to complete homework and exams due to inadequate resources (Liu et al., 2020; Tanhan, 2020; Yao et al., 2020). This demonstrated that technology should be employed with care in online or distance education (Tanhan, 2020; Wang et al., 2020). The current study findings suggested that similar problems were experienced.

The other significant themes that complicated distance/online education during the pandemic were the difference between distance and online education, non-interaction and inexperience. Student recommendations should be taken into account to improve the quality of distance/online education. Demands and needs of students play a critical role in the design and improvement of education systems. This should be one of the most important factors that higher education institutions pay attention to develop quality management systems to determine the expectations of the students from higher education and measure the service quality by empathizing with the students. Related departments in universities should investigate the reasons and results of student assessments and produce solutions that address negative assessments. This work should be repeated regularly, and the success of the novel measures should be monitored. Regular and continuous application of these procedures and similar studies could serve as important instruments for the universities to improve the quality of education (Dursun et al., 2013; Tanhan, 2020).

The present study findings demonstrated that the main themes that complicated distance/online education during the pandemic included non-interaction and inexperience. Non-interaction/lack of communication was experienced between the students and the teachers, and between the student and parents. In the pandemic, students, instructors and parents were inexperienced in distance/online education technologies and several other topics. This finding is also supported by Tanhan (2020) study, some of the college students as the participants reported getting used to online education gradually. According to Strommen (1992), the required changes in the education system were hampered by the lack of information technologies and timely use of these technologies by teachers and administrators. The lack of technological infrastructure led to problems experienced by the students in distance/online education during the COVID-19 pandemic. Although Gökçearslan et al. (2019) reported that the 
information and communication technology competencies of pre-service teachers were good, one of the main themes that complicated the distance/online education during the pandemic was inexperience of the parties in information technologies.

The fact that the factors that complicated distance/online education during the COVID-19 pandemic such as the uncertainty of the future, monotony, emotion(s), unproductivity, nature and the universe were prominent in the study suggested that these themes were a consequence of the quarantine and related events that people experienced during the pandemic. According to Özen and Temizsu (2010), human emotions such as despair, sadness-anxiety, low self-confidence, negative cognitive bias, self-criticism, self-esteem and indecision reflect the uncertainty associated with daily and/or future events. The uncertainty experienced due to these emotions is also related to these concepts and could lead to serious problems in critical periods such as COVID-19. In the pandemic, the main themes that complicated distance/online education such as unproductivity led to emotions of uneasiness, loneliness and powerlessness.

\section{The distribution of facilitating and complicating factors based on Ecological Systems Theory (EST)}

In this section of the study, the agreement of the participants with Ecologic Systems Theory (EST) levels was discussed. Individual/personal EST factors included the lack of computer or smart phone ownership, low education and income levels, etc., microsystem factors included inadequate family, school, etc. environment and inadequate technological facilities in these environments, exosystem factors included inadequacy of technological facilities in the media, neighbors, social services, local governments, and local organizations, macrosystem factors included problems associated with government policies, social values, economy, and international organizations. Since one factor can be related to different system levels (Tanhan, 2019; Tanhan \& Francisco, 2019), participants were given the right to attribute factors to more than one level. The following distribution respectively was observed for the factors that facilitated or complicated distance/online education during the COVID-19 pandemic based on EST: individual / personal $(\mathrm{n}=97,84.3 \% ; \mathrm{n}=79,68.7 \%)$; microsystem $(\mathrm{n}=52,45.2 \% ; \mathrm{n}=68,59.1 \%)$; exosystem $(\mathrm{n}=$ $41,35.7 \% ; \mathrm{n}=49,42.6 \%)$; macrosystem $(\mathrm{n}=39,33.9 \% ; \mathrm{n}=51,44.3 \%)$.

Participants attributed the factors that facilitated distance/online education to the individual/personal system, microsystem, exosystem and macrosystem factors, respectively. Participants mostly attributed the factors that complicated distance/online education during the COVID-19 pandemic to the individual/personal system, followed by the microsystem factors such as inadequate family, school, etc. environment and inadequate technological facilities in these environments. Thirdly, complicating factors was attributed to the macrosystems such as the inadequacy of government policies, social values, economy, and international organizations. Finally, they were attributed to the exosystem factors such as the inadequacy of technologies in the media, neighbors, social services, local governments, and local organizations. The prominent themes that complicated distance/online education during the COVID-19 pandemic the prominent themes attributed to the EST levels were consistent in the study.

\section{Limitations}

The study data were collected from college students, teachers, and academicians. Data were obtained collected with an online form. Due to the inability to determine the sincerity of participant statements, only volunteering participants were asked to fill the form.

Another limitation of the present study was the selection of adequate electronic device owners as participants since the study was conducted online during the pandemic. Individuals who did not have access to electronic devices most probably could not participate in the study due to lack of the required facilities. The authors believe that the lack of a device with a good camera, the COVID-19 curfews, and the risk of virus transmission forced certain participants to find, download and use stock photos from the internet. In OPV, although the meaning and advantages of taking their own photos were explained to the participants, it was noted that non-copyrighted open access internet photos could also be used in compliance with ethical rules. Another limitation of the study was the fact that the study results were not shared with the relevant individuals, institutions and participants in an actual exhibition and social event as recommended by Tanhan (2020) and Tanhan and Strack (2020). Instead, active advocacy was conducted only on virtual media and other online channels. The limitation of the present study associated with the participants was the fact that although individuals from all regions in Turkey participated in the study, most were from the eastern and southeastern regions. The final limitation of the study was the fact that participants were asked to identify the factors that facilitated and complicated distance/online education during the COVID-19 pandemic. In addition to these basic limitations, the fact that OPV method was used for the first time in an educational study, the time that the subjects were allowed to participate in the study, and the COVID-19 pandemic context should be considered. Furthermore, the participants were asked to identify at least one and at most three themes for facilitating and complicating factors. 
The study findings and conclusions were developed especially in the contexts of education and active advocacy. Recommendations based on the OPV employed in the study, contextual conditions and tackled topics are presented. The OPV technique/method developed by Tanhan and Strack (2020) and adapted to Turkish by Tanhan (2020) was employed in the study. The main objective of the OPV is to understand a topic based on the perspectives and stories of the participants to improve the psychological resilience of the participants as mentioned by certain authors (Tanhan, 2020; Tanhan et al., 2020). In the pandemic, the distribution of the factors that facilitated or complicated distance/online education were compared with the main themes. According to some authors (Tanhan, 2020; Tanhan \& Francisco, 2019; Tanhan \& Strack, 2020) psychological resilience is only possible through cooperation and increasing the capacities of all systems in the EST instead of one individual, group, institution or organization.

\section{Recommendations}

The following recommendations are presented based on the study findings, discussion and results: The factors that facilitate education during the COVID-19 pandemic and similar extraordinary cases are the adequacy of technological infrastructure and free internet access. Thus, educational institutions and organizations should improve the infrastructure and develop various solutions for internet access.

To ensure equal opportunity in distance/online education, different socioeconomic levels of the students should also be taken into account. Furthermore, various measures should be taken to improve the validity and reliability of measurement and evaluation in e-exams or distance/online exams based on the principle of equal opportunity. Further studies and applications could be developed to ensure objectivity and justice in online exams.

If the education will not be conducted in a face-to-face physical environment, care should be taken to ensure that the courses are conducted online (live, online) by providing an adequate technological infrastructure, free internet access, and technological knowledge and competence for the students and instructors. Online (live, online) course videos and other documents should be uploaded to the system for students to watch/view later.

Although students are provided with a technological infrastructure and free internet access in distance or online education, online mental health services could be provided to the students to prevent emotions such as loneliness and uneasiness, etc. using distance education tools.

To ensure comprehension in online or distance courses, the use of augmented reality should be improved in education and the "augmented reading" technique should be employed.

\section{References}

Abdüsselam, M. S., \& Karal, H. (2012). Fizik öğretiminde artırılmış gerçeklik ortamlarının öğrenci akademik başarısı üzerine etkisi: 11. sınıf manyetizma konusu örneği. Ĕgitim ve Öğretim Araştırmaları Dergisi, 1(4), 170-181.

Adnan, M., \& Anwar, K. (2020). Online learning amid the COVID-19 pandemic: students' perspectives. Journal of Pedagogical Sociology and Psychology, 2(1), 45-51. https://doi.org/10.33902/JPSP.2020261309

Akyol, G., Başkan, A. H., \& Başkan, A. H. (2020). Yeni tip koronavirüs (Covid-19) döneminde spor bilimleri fakültesi öğrencilerinin karantina zamanlarında yaptiklari etkinlikler ve sedanter bireylere önerileri. Avrasya Sosyal ve Ekonomi Araştırmaları Dergisi, 7(5), 190-203.

Alexander, S., \& Golja, T. (2007). Using students' experiences to derive quality in an e-learning system: An institution's perspective. Educational Technology \& Society, 10(2), 17-33.

Allen, I. E., \& Seaman, J. (2008). Staying the course: Online education in the United States. Needham, MA: The Sloan Consortium.

Allen, M., Bourhis, J., Burrell, N., \& Mabry, E. (2002). Comparing student satisfaction with distance education to traditional classrooms in higher education: A meta-analysis. The American Journal of Distance Education, 16(2), 83-97. https://doi.org/10.1207/S15389286AJDE1602_3

Arslan, G. (2020). Loneliness, college belongingness, subjective vitality, and psychological adjustment during coronavirus pandemic: Development of the College Belongingness Questionnaire. Journal of Positive School Psychology. https://doi.org/10.31234/osf.io/j7tf2

Arslan, G., \& Tanhan, A. (2019). Ergenlerde okul aidiyeti, okul işlevleri ve psikolojik uyum arasındaki ilişkinin incelenmesi [examining the association between school belonging, school functioning, and psychological adjustment in adolescents]. Journal of Education for Life, 33(2), 318-332. https://doi.org/10.33308/26674874.2019332127 
Arslan, G., Allen, K. A., \& Tanhan, A. (2020a). School bullying, mental health, and wellbeing in adolescents: mediating impact of positive psychological orientations. Child Indicators Research, 1-20. https://doi.org/10.1007/s12187-020-09780-2

Arslan, G., Yıldırım, M., Tanhan, A., Buluş, M., \& Allen, K. A. (2020b). Coronavirus stress, optimism-pessimism, psychological inflexibility, and psychological health: Psychometric properties of the coronavirus stress measure. International Journal of Mental Health and Addiction. https://doi.org/10.1007/s11469-020-00337-6

Becker, S. P., Langberg, J. M., \& Byars, K. C. (2015). Advancing a biopsychosocial and contextual model of sleep in adolescence: A review and introduction to the special issue. J Youth Adolescence, 44, 239-270. https://doi.org/10.1007/s10964-014-0248-y

Biner, P. M., Bink, M. L., Huffman, M. L., \& Dean, R. S. (1995). Personality characteristics differentiating and predicting the achievement of televised-course students and traditional-course students. American Journal of Distance Education, 9(2), 46-60. https://doi.org/10.1080/08923649509526887

Bliuc, A. M., Goodyear, P., \& Ellis, R. A. (2007). Research focus and methodological choices in studies into students' experiences of blended learning in higher education. The Internet and Higher Education, 10, 231-244. https://doi.org/10.1016/j.iheduc.2007.08.001

Bozkurt, A., \& Uçar, H. (2018). E-öğrenme ve e-sınavlar: çevrimiçi ölçme değerlendirme süreçlerinde kimlik doğrulama yöntemlerine ilişkin öğrenen görüşlerinin incelenmesi. Mersin Üniversitesi Eğitim Fakültesi Dergisi, 14(2), 745-755. https://doi.org/10.17860/mersinefd.357339

Bronfenbrenner, U. (1977). Toward an experimental ecology of human development. American Psychologist, 32(7), 513-531. https://doi.org/10.1037/0003-066X.32.7.513

Bronfenbrenner, U. (1979). The ecology of human development. Harvard university press.

Bronfenbrenner, U., \& Evans, G. W. (2000). Developmental science in the 21st century: Emerging questions, theoretical models, research designs and empirical findings. Social Development, 9(1), 115-125. https://doi.org/10.1111/1467-9507.00114

Brown, B. W., \& Liedholm, C. E. (2002). Can web courses replace the classroom in principles of microeconomics? American Economic Review, 92(2), 444-448. https://doi.org/10.1257/000282802320191778

Cao, W., Fang, Z., Hou, G., Han, M., Xu, X., Dong, J., \& Zheng, J. (2020). The psychological impact of the COVID-19 epidemic on college students in China. Psychiatry Research, 112934. https://doi.org/10.1016/j.psychres.2020.112934

Çetin, C., \& Anuk, Ö. (2020). COVID-19 pandemi sürecinde yalnizlik ve psikolojik dayaniklilik: Bir kamu üniversitesi öğrencileri örneklemi. Avrasya Sosyal ve Ekonomi Araştırmaları Dergisi, 7(5), 170-189.

Çıtak, Ş., \& Pekdemir, Ü. (2020). An analysis on sleep habits and generalized anxiety levels of individuals during the COVID-19 pandemic. Journal of Family Counseling and Education, 5(1), 60-73. https://doi.org/10.32568/jfce.742086

Coates, H., James, R., \& Baldwin, G. (2005). A critical examination of the effects of learning management systems on university teaching and learning. Tertiary Education and Management, 11, 19-36. https://doi.org/10.1080/13583883.2005.9967137

Cortese, S., Asherson, P., Sonuga-Barke, E., Banaschewski, T., Brandeis, D., Buitelaar, J., \& Doepfner, M. (2020). ADHD management during the COVID-19 pandemic: Guidance from the European ADHD Guidelines Group. The Lancet Child \& Adolescent Health. https://doi.org/10.1016/S2352-4642(20)30110-3

Crawford, J., Butler-Henderson, K., Rudolph, J., \& Glowatz, M. (2020). COVID-19: 20 countries' higher education intra-period digital pedagogy responses. Journal of Applied Teaching and Learning (JALT), 3(1). https://doi.org/10.37074/jalt.2020.3.1.7

Cucinotta, D., \& Vanelli, M. (2020). WHO declares COVID-19 a pandemic. Acta Bio-Medica: Atenei Parmensis, 91(1), 157-160.

Dhawan, S. (2020). Online learning: A panacea in the time of COVID-19 crisis. Journal of Educational Technology Systems, 1-18. https://doi.org/10.1177/0047239520934018

Diekhoff, G. M., LaBeff, E. E., Clark, R. E., Williams, L. E., Francis, B., \& Haines, V. J. (1996). College cheating: Ten years later. Research in Higher Education, 37(4), 487-502. https://doi.org/10.1007/BF01730111 
Dursun, T., Oskayba, K., \& Gökmen, C. (2013). The quality of service of the distance education. Procedia-Social and Behavioral Sciences, 103, 1133-1151. https://doi.org/10.1016/j.sbspro.2013.10.441

Emir Öksüz, E., \& Brubaker, M. D. (2020). Deconstructing disability training in counseling: a critical examination and call to the profession. Journal of Counselor Leadership and Advocacy, 1-13. https://doi.org/10.1080/2326716X.2020.1820407

Erbaş, Ç., \& Demirer, V. (2015). Eğitimde artırılmış gerçeklik uygulamaları: Google glass örneği. Journal of Instructional Technologies and Teacher Education, 3(2), 8-16. Retrieved from https://dergipark.org.tr/tr/pub/jitte/issue/25084/264728

Ersoy, H., Duman, E., \& Öncü, S. (2016). Artırılmış gerçeklik ile motivasyon ve başarı: deneysel bir çalışma. Journal of Instructional Technologies \& Teacher Education, 5(1), 39-44.

Gençalp, D. K. (2020). COVID-19 salgını döneminde ilk ve acil yardım öğrencilerinin beslenme alışkanlıkları ve fiziksel aktivite durumlarının değerlendirilmesi. Paramedik ve Acil Sağllk Hizmetleri Dergisi, 1(1), 1-15.

Girik Allo, M. D. (2020). Is the online learning good in the midst of covid-19 pandemic? The case of EFL learners. Jurnal Sinestesia, 10/1, 1-10.

Gökçearslan, Ş., Karademir Coşkun, T., \& Şahin, S. (2019). Öğretmen adayı bilgi ve iletişim teknolojisi yeterlikleri ölçeğinin Türkçeye uyarlanması. Kastamonu Eğitim Dergisi, 27(4), 1435-1444. https://doi.org/10.24106/kefdergi.2828

Goodhart, F. W., Hsu, J., Baek, J. H., Coleman, A. L., Maresca, F. M., \& öer, M. B. (2006). A view through a different lens: Photovoice as a tool for student advocacy. Journal of American College Health, 55(1), 53-56. https://doi.org/10.3200/JACH.55.1.53-56

Gumusgul, O., \& Aydoğan, R. (2020). Yeni tip koronavirüs-covid 19 kaynaklı evde geçirilen boş zamanların ev içi rekreatif oyunlar ile değerlendirilmesi. Spor Ĕgitim Dergisi, 4(1), 107-114.

Haines, V. J., Diekhoff, G. M., LaBeff, E. E., \& Clark, R. E. (1986). College cheating: immaturity, lack of commitment, and the neutralizing attitude. Res High Educ, 25(4), 342-354. https://doi.org/10.1007/BF00992130

Hanuku, E. A. (2020). COVID-19: Online learning experience of college students: the case of Ghana. International Journal of Multidisciplinary Sciences and Advanced Technology, 1(2), 54-62.

Helgesen, O., \& Nesset, E. (2007). Images, satisfaction and antecedents: drivers of student loyalty? A case study of a Norwegian university college. Corporate Reputation Review, 10(1), 38-59. https://doi.org/10.1057/palgrave.crr.1550037

Huang, C., Wang, Y., Li, X., Ren, L., Zhao, J., Hu, Y., Zhang, L., Fan, G., Xu, J., Gu, X., Cheng, Z., Yu, T., Xia, J., Wei, Y., Wu, W., Xie, X., Yin, W., Li, H., Liu, M., Cao, B., .. \& Caot., B. (2020). Clinical features of patients infected with 2019 novel coronavirus in Wuhan, China. The Lancet, 395(10223), 497-506. https://doi.org/10.1016/S0140-6736(20)30183-5

Jung, I. Y., \& Yeom, H. Y. (2009). Enhanced security for online exams using group cryptography. IEEE transactions on Education, 52(3), 340-349. https://doi.org/10.1109/TE.2008.928909

Kaufmann, H. (2003). Collaborative augmented reality in education. Proceedings of Imagina 2003 conference, 1-4.

Kaur, G. (2020). Digital Life: Boon or bane in teaching sector on COVID-19. CLIO an Annual Interdisciplinary Journal of History, 6(6), 416-427.

Kirby, E. (1999). Building interaction in online and distance education courses. In J. Price, J. Willis, D. Willis, M. Jost \& S. Boger-Mehall (Eds.), Proceedings of SITE 1999--Society for Information Technology \& Teacher Education International Conference (pp. 199-205). Waynesville, NC USA: Association for the Advancement of Computing in Education (AACE). Retrieved from https://www.learntechlib.org/p/7941

Kiymaz, M. S., \& Doyumğaç, I. (2020). The views of turkish language teachers and primary school teachers on teacher guidebooks. Journal of Curriculum and Teaching, 9(3), 88-106. https://doi.org/10.5430/jct.v9n3p88

Kürtüncü, M., \& Kurt, A. (2020). COVID-19 pandemisi döneminde hemşirelik öğrencilerinin uzaktan eğitim konusunda yaşadiklari sorunlar. Avrasya Sosyal ve Ekonomi Araştırmaları Dergisi, 7(5), 66-77.

Lack, K. A. (2013). Current status of research on online learning in postsecondary education. ITHAKA S+R. Retrieved

from http://sr.ithaka.org/wpcontent/uploads/2015/08/ithaka-sr-online-learningpostsecondaryeducation-may2012.pdf 
Lee, B. C., Yoon, J. O., \& Lee, I. (2009). Learners' acceptance of e-learning in South Korea: Theories and results. Computers \& Education, 53, 1320-1329. https://doi.org/10.1016/j.compedu.2009.06.014

Lee, J. K., \& Lee, W. K. (2008). The relationship of e-learner's self-regulatory efficacy and perception of e-learning environmental quality. Computers in Human Behavior, 24, 32-47. https://doi.org/10.1016/j.chb.2006.12.001

Lee, J. W. (2010). Online support service quality, online learning acceptance, and student satisfaction. Internet and Higher Education, 13, 277-283. https://doi.org/10.1016/j.iheduc.2010.08.002

Lester, P. M., \& King, C. M. (2009). Analog vs. digital instruction and learning: Teaching within first and second life environments. Journal of Computer-Mediated Communication, 14, 457-483. https://doi.org/10.1111/j.1083-6101.2009.01449.x

Levy, Y. (2007). Comparing dropouts and persistence in e-learning courses. Computers \& Education, 48(2), 185-204. https://doi.org/10.1016/j.compedu.2004.12.004

Liguori, L., \& Winkler, C. (2020). From offline to online: challenges and opportunities for entrepreneurship education following the covid-19 pandemic. Entrepreneurship Education and Pedagogy, 1-6. https://doi.org/10.1177/2515127420916738

Liu, S., Yang, L., Zhang, C., Xiang, Y. T., Liu, Z., Hu, S., \& Zhang, B. (2020). Online mental health services in China during the COVID-19 outbreak. The Lancet Psychiatry, 7(4), e17-e18. https://doi.org/10.1016/S2215-0366(20)30077-8

Lucky, A., Branham, M., \& Atchison, R. (2019). Collection-based education by distance and face to face: learning outcomes and academic dishonesty. Journal of Science Education and Technology, 28, 414-428. https://doi.org/10.1007/s10956-019-9770-8

Mahalakshmi, R., \& Radha, K. (2020). COVID 19: A massive exposure towards web based learning. Journal of Xidian University, 14(4), 2405-2411. https://doi.org/10.37896/jxu14.4/266

Mailizar, Almanthari, A., Maulina, S., \& Bruce, S. (2020). Secondary school mathematics teachers' views on e-learning implementation barriers during the Covid-19 pandemic: The case of Indonesia. Eurasia Journal of Mathematics, Science and Technology Education, 16(7), em1860. https://doi.org/10.29333/ejmste/8240

Mamun, M. A., \& Griffiths, M. D. (2020). First COVID-19 suicide case in Bangladesh due to fear of COVID-19 and xenophobia: possible suicide prevention strategies. Asian Journal of Psychiatry, 51, 102073. https://doi.org/10.1016/j.ajp.2020.102073

McCarthy, K. (2020, March 7). The global impact of coronavirus on education. Retrieved from https://abcnews.go.com/International/global-impact-coronavirus-education/story?id=6941173

McGorry, S. Y. (2003). Measuring quality in online programs. The Internet and Higher Education, 6(2), 159-177. https://doi.org/10.1016/S1096-7516(03)00022-8

Minkler, M. (2000). Using participatory action research to build healthy communities. Public Health Reports, 115(2-3), 191. https://doi.org/10.1093/phr/115.2.191

Mulenga, E. M., \& Marbán, J. M. (2020). Prospective teachers' online learning mathematics activities in the age of covid-19: A cluster analysis approach. EURASIA Journal of Mathematics, Science and Technology Education, 16(9), 2-9. https://doi.org/10.29333/ejmste/8345

Nichols, M. (2008). Institutional perspectives: The challenges ofe-learning diffusion. British Journal of Educational Technology, 39/4, 598-609. https://doi.org/10.1111/j.1467-8535.2007.00761.x

Özarslan, Y. (2013). Genişletilmiş gerçeklik ile zenginleştirilmiş öğrenme materyallerinin ögrenen başarısı ve memnuniyeti üzerindeki etkisi. Doktora Tezi, Anadolu Üniversitesi, Eskişehir.

Özen, D. Ş., \& Temizsu, E. (2010). Anksiyete ve depresif bozukluklarda örtüșen ve ayrışan belirtiler. Psikiyatride Güncel Yaklaşımlar, 2(1), 1-14. Retrieved from http://cappsy.org/archives/vol2/no1/cap_02_01.pdf

Paechter, M., \& Maier, B. (2010). Online or face-to-face? Students' experiences and preferences in e-learning. Internet and Higher Education, 13, 292-297. https://doi.org/10.1016/j.iheduc.2010.09.004

Ramu, T., \& Arivoli, T. (2013). A framework of secure biometric based online exam authentication: an alternative to traditional exam. Int J Sci Eng Res, 4(11), 52-60. 
Rasmitadila, Rusmiati Aliyyah, R., Rachmadtullah, R., Samsudin, A., Syaodih, E., Nurtanto, M., \& Suryanti Tambunan, A. R. (2020). The perceptions of primary school teachers of online learning during the COVID-19 pandemic period: A case study in Indonesia. Journal of Ethnic and Cultural Studies, 7/2, 90-109. https://doi.org/10.29333/ejecs/388

Rose, S. (2020). Medical student education in the time of COVID-19. JAMA, 323(21), 2131-2132. https://doi.org/10.1001/jama.2020.5227

Rovai, A. P. (2003). A practical framework for evaluating online distance education programs. The Internet and Higher Education, 6(2), 109-124. https://doi.org/10.1016/S1096-7516(03)00019-8

Sarıtaş, E., \& Barutçu, S. (2020). Öğretimde dijital dönüşüm ve öğrencilerin çevrimiçi öğrenmeye hazır bulunuşluğu: Pandemi döneminde Pamukkale Üniversitesi öğrencileri üzerinde bir araştırma. Internet Uygulamalarl ve Yönetimi Dergisi, 11(1), 5-22. https://doi.org/10.34231/iuyd.706397

Sayk1l1, A. (2018). Distance education: Definitions, generations, key concepts and future directions. International Journal of Contemporary Educational Research, 5(1), 2-17.

Shelton, B. E., \& Hedley, N. R. (2002). Using augmented reality for teaching earth-sun relationship to undergraduate geography students. The First IEEE International Augmented Reality Toolkit Workshop, 1-8. https://doi.org/10.1109/ART.2002.1106948

Singh, R., \& Hurley, D. (2017). The effectiveness of teaching and learning process in online education as perceived by university faculty and instructional technology professionals. Journal of Teaching and Learning with Technology, 6(1), 65-75. https://doi.org/10.14434/jotlt.v6.n1.19528

Sırakaya, M. (2016). Artırılmış gerçekliğin uygulamalı eğitimde kullanımı: Anakart montajı. Ahi Evran Üniversitesi Kırşehir Eğitim Fakültesi Dergisi (KEFAD), 17/3, 301-316.

Sönmez, V., \& Alacapınar, F. G. (2013). Örneklendirilmiş bilimsel araştırma yöntemleri. Ankara: Anı.

Stiles, B. L., Wong, N. C. W., \& LaBeff, E. E. (2018). College cheating thirty years later: the role of academic entitlement. Deviant Behav, 39(7), 823-834. https://doi.org/10.1080/01639625.2017.1335520

Strommen, E. F. (1992). Constructivism, technology, and the future of classroom learning. Education And Urban Society, 24/4, 466-476. https://doi.org/10.1177/0013124592024004004

Tanhan, A. (2019). Acceptance and commitment therapy with ecological systems theory: Addressing Muslim mental health issues and wellbeing. Journal of Positive Psychology and Wellbeing, 3(2), 197-219. https://doi.org/10.47602/jpsp.v3i2.172

Tanhan, A. (2020). COVID-19 sürecinde online seslifoto (OSF) yöntemiyle biyopsikososyal manevi ve ekonomik meseleleri ve genel iyi oluş düzeyini ele almak: OSF'nin Türkçeye uyarlanması. [Utilizing online photovoice (OPV) methodology to address biopsychosocial spiritual economic issues and wellbeing during COVID-19: Adapting OPV to Turkish.] Turkish Studies, 15(4), 1029-1086. https://doi.org/10.7827/TurkishStudies.44451

Tanhan, A., \& Francisco, V. T. (2019). Muslims and mental health concerns: A social ecological model perspective. Journal of Community Psychology, 47(4), 964-978. https://doi.org/10.1002/jcop.22166

Tanhan, A., \& Strack, R. W. (2020). Online photovoice to explore and advocate for Muslim biopsychosocial spiritual wellbeing and issues: Ecological systems theory and ally development. Current Psychology, 1-16. https://doi.org/10.1007/s12144-020-00692-6

Tanhan, A., Yavuz K. F., Young, J. S., Nalbant, A., Arslan, G., Yıldırım, M., Ulusoy, S., Genç, E., Uğur, E., \& Çiçek, İ. (2020). A proposed framework based on literature review of online contextual mental health services to enhance wellbeing and address psychopathology during COVID-19. Electronic Journal of General Medicine, 17(6), em254. https://doi.org/10.29333/ejgm/8316

Toquero, C. M. (2020). Challenges and opportunities for higher education amid the COVID-19 pandemic: The philippine context. Pedagogical Research, 5(4), em0063. https://doi.org/10.29333/pr/7947

Tria, J. Z. (2020). The COVID-19 Pandemic through the lens of education in the Philippines: The New Normal. International Journal of Pedagogical Development and Lifelong Learning, 1(1), 2-4. https://doi.org/10.30935/ijpdll/8311 
Ubell, R. (2017). Online cheating. Inside Higher Education. (February 6, 2017). Retrieved from https://www.insidehighered.com/digital-learning/views/2017/02/06/robert-ubell-online-cheating-and-what-colle ges-can-do-about-it

Uğur, E., Kaya, Ç., \& Tanhan, A. (2020). Psychological inflexibility mediates the relationship between fear of negative evaluation and psychological vulnerability. Current Psychology. https://doi.org/10.1007/s12144-020-01074-8

Vandehey, M. A., Diekhoff, G. M., \& LaBeff, E. E. (2007). College cheating: a twenty-year follow-up and the addition of an honor code. J Coll Stud Dev, 48(4), 462-480. https://doi.org/10.1353/csd.2007.0043

Viner, R. M., Russell, S. J., Croker, H., Packer, J., Ward, J., Stansfield, C., ... \& Booy, R. (2020). School closure and management practices during coronavirus outbreaks including COVID-19: a rapid systematic review. The Lancet Child \& Adolescent Health, 4(5), 397-404. https://doi.org/10.1016/S2352-4642(20)30095-X

Wang, C., \& Burris, M. A. (1997). Photovoice: Concept, methodology, and use for participatory needs assessment. Health Education \& Behavior, 24(3), 369-387. https://doi.org/10.1177/109019819702400309

Wang, C., Cheng, Z., Yue, X.-G., \& McAleer, M. (2020). Risk Management of COVID-19 by universities in China. Journal of Risk and Financial Management, 13(2), 36. http://doi.org/10.3390/jrfm13020036

World Health Organization. (2020, Nisan 20). Naming the coronavirus disease (COVID-19) and the virus that causes it.

Wu, D. D. (2015). Online learning in postsecondary education: a review of the empirical literature (2013-2014). ITHAKA $S+R$. https://doi.org/10.18665/sr.221027

Yao, H., Chen, J. H., \& Xu, Y. F. (2020). Rethinking online mental health services in China during the COVID-19 epidemic. Asian Journal of Psychiatry, 50, 102015. https://doi.org/10.1016/j.ajp.2020.102015

\section{Copyrights}

Copyright for this article is retained by the author(s), with first publication rights granted to the journal.

This is an open-access article distributed under the terms and conditions of the Creative Commons Attribution license (http://creativecommons.org/licenses/by/4.0/). 